NBER WORKING PAPER SERIES

CONTRACTUAL VERSUS GENERIC OUTSOURCING:

THE ROLE OF PROXIMITY

\author{
Robert C. Feenstra \\ Barbara J. Spencer \\ Working Paper 11885 \\ http://www.nber.org/papers/w11885
}

\author{
NATIONAL BUREAU OF ECONOMIC RESEARCH \\ 1050 Massachusetts Avenue \\ Cambridge, MA 02138 \\ December 2005
}

We would like to thank Chang Hong for her very helpful assistance with the empirical research. Barbara Spencer is also grateful for financial support from the Social Science and Humanities Research Council of Canada. The views expressed herein are those of the author(s) and do not necessarily reflect the views of the National Bureau of Economic Research.

(C2005 by Robert C. Feenstra and Barbara J. Spencer. All rights reserved. Short sections of text, not to exceed two paragraphs, may be quoted without explicit permission provided that full credit, including () notice, is given to the source. 
Contractual Versus Generic Outsourcing: The Role of Proximity

Robert C. Feenstra and Barbara J. Spencer

NBER Working Paper No. 11885

December 2005

JEL No. F1, L24

\begin{abstract}
$\underline{\text { ABSTRACT }}$
We explore the relationship between proximity of buyers and sellers and the organizational form of outsourcing. Outsourcing can be "contractual" in which suppliers undertake specific investments or involve "generic" market transactions. Proximity expands the variety of products sourced through contracts abroad rather than at home, but the range of generic imports is unchanged. A higher-quality foreign workforce raises the variety of contractual trade, but at the expense of generics. We confirm these predictions using data for ordinary versus processing exports from Chinese provinces to destination markets and also the predictions of an extended model that allows for multinational production.
\end{abstract}

Robert C. Feenstra

Department of Economics

University of California

Davis, CA 95616

and NBER

rcfeenstra@ucdavis.edu

Barbara J. Spencer

University of British Columbia

Sauder School of Business

2053 Main Mall

Vancouver, BC V6T 1Z2 CANADA

and NBER

barbara.spencer@sauder.ubc.ca 


\section{Contractual versus Generic Outsourcing: The Role of Proximity}

\section{Introduction}

The importance of distance in international trade has been well-established by empirical work on the gravity equation. Beyond its influence on the volume of trade, however, distance can also have an impact on the organization of trade and production. For example, Evans and Harrigan (2005) have recently shown the importance of proximity between the buyer and seller in the sourcing of apparel production. More generally, we will argue in this paper that proximity between buyers and sellers is a key determinant of the contractual relations between parties engaged in international outsourcing.

To provide an illustration of the contractual relations we have in mind, consider Figure 1. There we show the manufacturing exports of China to various destination countries in 2002, broken down into the proportions accounted for by “ordinary” exports, processing exports by Chineseowned firms (labelled “other processing”), and processing exports by foreign-owned firms (labelled “FDI processing”). Processing exports are produced under contractual arrangements with foreign firms, whereas “ordinary” exports do not have these arrangements. Figure 1(A) shows the dollar amount of trade, and Figure 1(B) shows percentages. These proportions of trade are quite different across destination countries. For example, Japan (the closest country) imports the greatest proportion of goods as FDI processing, followed by the United States (a distant but very large country), European Union, ASEAN countries, Canada, South America and South Africa.

Apart from the distance from China to various destination countries, another aspect of proximity is the distance from a Chinese province to the nearest port or land border. There are huge differences across the 30 Chinese provinces in their proximity to the coast, and as a result, in their 
levels of exports and proportions of ordinary versus processing trade. Some examples are illustrated in Figure 2, where Figure 2(A) shows the dollar amount of trade and Figure 2(B) shows percentages. We see that the coastal province of Guangdong has the highest exports and the greatest proportion in FDI processing, followed by Fujian/Hainan, Beijing/Tianjin, Shanghai, and other coastal regions. Inland areas, by contrast, have little processing trade in general, and even less accounted for by foreign-owned firms.

With these examples in mind, we explore the relationship between proximity of the buyer and seller and the organizational form of outsourcing. Our point of departure is recent literature in international trade dealing with incomplete contracts between firms in the provision of specialized inputs. ${ }^{1}$ This literature has mostly emphasised the importance of proximity with respect to the ability to enforce contracts, monitor workers or gain information. ${ }^{2}$ But the role of proximity is more complicated than that, because distance also affects the outside options of the firms involved in a contractual outsourcing relationship. In this paper, the outside option for the buyer is to purchase non-specialized parts on the spot market, referred to as "generic outsourcing." 3 Because distance

\footnotetext{
${ }^{1}$ For example, Antràs (2003) argues that in more capital-intensive industries, a greater share of trade is "intra-firm," i.e. between a parent and its subsidiaries. Antràs and Helpman (2004) analyse a more general multi-industry, multi-country model, where the type of contracts and ownership between firms will depend on features of the industry (the productivity distribution of firms) as well features of the host countries (such as factors prices). See Helpman (2005) and Spencer (2005) for surveys.

${ }^{2}$ For example, Antras (2005) assumes that contracts between firms in different countries are harder to enforce than contracts between firms in the same country. Grossman and Helpman (2004) suppose that it is easier to monitor workers at home. Head, Ries and Spencer (2004) emphasizes the importance of local information about the buyer's needs in designing relationship-specific investments.

${ }^{3}$ Spencer and Qiu (2001), Qiu and Spencer (2002) and Head, Ries and Spencer (2004) incorporate the spot-market purchase of generic parts as an outside option for a buyer in a model of incomplete contracts. In Head, Ries and Spencer (2004), multinational firms producing abroad may contract with home country suppliers, but otherwise these papers focus on domestic contractual outsourcing. The recent work of Schwartz and Van Assche (2005) also examines contractual (or “ideal”) outsourcing versus arm's length purchases of inputs in an international context.
} 
affects the price of generic inputs, it affects the outside option under Nash bargaining and hence the outcome from contractual outsourcing. It is this linkage between distance, generic outsourcing and contractual outsourcing that we investigate, both theoretically and empirically.

In the model described in sections 2 and 3 there are two countries, a high-wage country and a low-wage country. The buyer is located in the high-wage country, while suppliers can be located in either country or can take the form of a multinational with headquarters in the high-wage country and production in the low-wage country. Contacts are assumed to be incomplete: suppliers make an up-front relationship-specific investment so as to specialize an input, but are rewarded only through ex-post bargaining over the price of the component or part. Since the threat-point of the buyer involves the import of a generic parts from a spot-market in the low-wage country, the alternative to contractual outsourcing is arm's length purchases as in standard models of perfect competition and trade.

To provide some intuition as to the workings of the model, suppose that the marginal cost of buying abroad falls, as would occur due to a reduction in transport costs. Then the model predicts that the profits of contractual exporters from the low wage country would be unchanged for any given level of exports. This occurs because the reduction in cost applies to generic as well as contractual goods with the result that the buyer's outside option of arm's-length purchases improves by the amount of the cost decrease. Nash bargaining then implies that the contracted price will fall by the same amount as the arm's length price and the cost decrease. Consequently, a reduction in foreign costs has no effect on the buyer's choice between contractual and generic imports. But the tradeoff between foreign and domestic contractual outsourcing is affected, since the former is cheaper. As a result, the low-wage country exports a greater range of goods under contractual arrangements, displacing contractual production in the high wage country. This gives rise to an 
important prediction for the empirical analysis: lower trade costs due to closer proximity to a lowwage country should be associated with a higher proportion of imported varieties that are of the contractual rather than the generic type.

We examine this hypothesis empirically in section 3, using data on processing versus “ordinary” exports from Chinese provinces to various destination countries. ${ }^{4}$ As their name suggests, processing exports are goods that rely on imported inputs that are processed in China with the finished good exported. Provided the finished good is not sold domestically, Chinese customs authorities allow the imported inputs to enter the country duty free. We presume that all such relationships are contractual, in the sense that the buyer specifies the characteristics of the good and makes payment accordingly. In contrast, "ordinary” exports are goods that could be equally well sold domestically, and have no special customs treatment. We presume that these exports are not specialized for a particular buyer and represent arm's-length transactions between unrelated firms, like the "generic" outsourcing in our model.

In section 4, we extend the model to include the possibility of contractual outsourcing to a multinational firm that has headquarters in the high-wage country, but produces through FDI (foreign direct investment) in the low-wage country. Again, we generate predictions about the variety of goods that would be produced under FDI versus under the two forms of outsourcing. Under mild assumptions, we find that the most technologically sophisticated inputs are produced domestically through contractual outsourcing to domestic firms; the next most sophisticated are contracted to multinational firms producing through FDI; products with even less sophistication are

\footnotetext{
${ }^{4}$ Feenstra and Hanson (2005) use Chinese data similar to that used here to examine two types of processing exports, depending on which party (the Chinese manager or foreign firm) own and controls the imported inputs. In contrast, we are comparing processing exports (by either Chinese-owned or foreignowned firms) with the variety of ordinary exports.
} 
produced through contractual outsourcing directly to firms in the low-wage country; and the simplest inputs are produced and exported under generic outsourcing. As before, a decrease in trade costs should increase the proportion of exported varieties that are of the contractual type, but the increase should be concentrated in an expansion of multinational production rather than contractual outsourcing to unaffiliated firms in the low-wage country.

For the empirical analysis, we are interested in explaining processing exports versus ordinary exports as well as the extent of foreign ownership within the processing category. We find support for the theoretical predictions of our model. Specifically, we find that the range of processing exports from Chinese provinces are much more sensitive to internal distance (from the province to the nearest shipping port or major border crossing) than are ordinary exports. More remote provinces have a lower variety of processing exports relative to ordinary exports, as already suggested by Figure 2. In contrast to the proportions of total trade as shown in Figure 2, however, our results are obtained by using the export variety - or "extensive margin" - of ordinary exports versus processing exports. The negative effect of distance on the variety of processing exports is reinforced by having a lower quality provincial workforce, which also tilts trade towards ordinary exports and away from processed varieties. Furthermore, within processing exports, it is foreign-owned multinational firms that are the most sensitive to distance and to the quality of the workforce: a province that is closer to the border or has a higher-quality workforce will have relatively more processed varieties exported by foreign-owned firms.

Our empirical results therefore provide support for the main predictions of our model. Beyond that, our empirical method is of some general interest because it uses the "extensive margin" as the dependent variable in gravity-like equations. This technique has also been used recently by Chen and Feenstra (2005) and Hillberry and Hummels (2005), and enables us to quantify the impact 
of distance (and other variables) on the organizational structure of trade. These conclusions are discussed further in section 5.

\section{The Model.}

The model we develop is related to the work of Grossman and Helpman (2002, 2005), and the papers by Antràs cited above, which use the property-rights theory of Grossman and Hart (1986) to model global outsourcing. Likewise, we use a Grossman-Hart framework, which includes a relationship-specific investment (RSI) that a supplier must make, thereby creating a "holdup" problem. $^{5}$

There are two countries: a high-wage developed country, denoted by $\mathrm{H}$ and a low-wage developing country denoted by L. We model a buyer or "assembler” in country H that produces a final good using a fixed proportion of each of a large number of intermediate goods or parts. “Suppliers” in country $\mathrm{H}$ and country L potentially make relationship-specific investments so as produce innovations in design (blueprints) that specialize parts in ways that are of value only to the particular assembler. Contracts are incomplete in the sense that it is not possible to condition payment on the level of investment. Thus each supplier must make its investment up-front with the distribution of rents subsequently determined through ex-post bargaining. The assembler can choose to purchase specialized parts through contractual outsourcing in either country H or country L, but also has the option of purchasing "generic" versions of the parts from a spot market. Due to the cost advantage of production in L, generic parts are produced only in country L.

Figure 3 illustrates the various organizational forms, which are distinguished as follows:

\footnotetext{
${ }^{5}$ In contrast, Grossman and Helpman (2004) apply the incentive-systems framework of Holmstrom and Milgrom (1994) to model managerial compensation in global production, and Marin and Verdier (2002, 2003) and Puga and Trefler (2002) extend the Aghion and Tirole (1997) theory of delegation of authority to general equilibrium.
} 


\section{Contractual outsourcing:}

Domestic outsourcing - type $\mathbf{H}$ supplier, RSI and production in $\mathrm{H}$

Multinational supplier - type M supplier, RSI in H and production in L

Foreign outsourcing - type L supplier, RSI and production in L

Generic outsourcing: spot market in country L.

Suppliers undertake RSI only in their country of origin, but production can take place in either country. Thus, suppliers from country $\mathrm{H}$ have the option of producing at home or producing as a multinational through FDI in country L. Multinationals from $\mathrm{H}$ gain access to the lower wage in country L, but must pay a fixed cost, F, to set up a plant. However, suppliers from country L produce only in country L. ${ }^{6}$ Letting the index i represent these three organizational forms, then $\mathrm{i}=$ $\mathrm{L}$ if the contract is with a supplier in $\mathrm{L}, \mathrm{i}=\mathrm{H}$ if the contract is with a supplier in $\mathrm{H}$ with production in $\mathrm{H}$ and $\mathrm{i}=\mathrm{M}$ (for multinational) if a supplier in $\mathrm{H}$ undertakes RSI in $\mathrm{H}$, but produces in $\mathrm{L}$.

Parts differ with respect to the effectiveness of RSI in creating rent for the assembler. We interpret this variation as mainly reflecting differences in technological sophistication. Thus we would expect that parts with high effectiveness of RSI are the more technologically sophisticated inputs, that require significant investment to keep up with technological change. ${ }^{7}$ Letting $\rho(z) \in(0,1]$ denote the effectiveness of RSI for part $z$, parts are ordered from low to high $\rho(z)$ on the continuum $\mathrm{z} \in[0, \check{Z}]$, where $\rho(0)>0$ and $\rho(\check{Z})=1$. For convenience we assume that one unit of the final good requires just one of each of the intermediate goods. Following Spencer and Qiu (2001), we assume

\footnotetext{
${ }^{6}$ Suppliers from L producing in $\mathrm{H}$ would be dominated by suppliers from $\mathrm{H}$ that do not pay $\mathrm{F}$.
}

${ }^{7}$ Based on U.K. manufacturing data, Acemoglu et al. (2004) finds that outsourcing (rather than vertical integration by the buyer) is more likely when the supplier is technologically intensive. The effectiveness of RSI may also be increased by other factors such as a larger cost-share in final-good production (see Spencer and Qiu, 2001, and Acemoglu et. al. 2004). 
that the rent created by RSI takes the form of a reduction in marginal assembly costs. For example, the blueprints created by RSI could improve the fit of each part with the other parts involved in the assembly process or, alternatively, could speed up “just-in-time” delivery. As a result, the total rent created by any given level of RSI is increasing in the output of the assembler. The idea that the scale of a buyer increases the benefits from supplier investment seems appealing in considering the extensive contractual outsourcing of a firm such as Wal-Mart.

We introduce a minimum level of RSI, denoted $\underline{\mathrm{k}}$, that will later play an important role in distinguishing the various cases. The idea is that suppliers must invest $\underline{\mathrm{k}}$ just to obtain a basic knowledge of the assembler's requirements. For example, $\underline{\mathrm{k}}$ could include the set up costs for an R\&D lab. Letting $\mathrm{k}$ represent the level of RSI, it follows that only the portion, $\mathrm{k}-\underline{\mathrm{k}}$, of this investment is effective in creating rent. Thus we assume that an investment, $\mathrm{k}$, by a supplier of type $\mathrm{i}=\mathrm{H}$ creates rent, $\mathrm{r}^{\mathrm{H}}$, in the form of a reduction in assembly cost for each unit purchased, where

$$
\mathrm{r}^{\mathrm{H}} \equiv \rho(\mathrm{z})(\mathrm{k}-\underline{\mathrm{k}})^{1 / 2} .
$$

The functional form in (1) implies that rent per unit is increasing in $\mathrm{k}$, but at a decreasing rate. Letting y represent the assembler's (and the supplier's) output, the total rent created is $\mathrm{r}^{\mathrm{H}} \mathrm{y}$.

Multinationals of type $\mathrm{M}$ undertaking production in the low-wage country are less efficient than suppliers of type $\mathrm{H}$ in the quality of manufacture of specialized inputs due to lower skill in the workforce. Letting $\mathrm{q} \in(0,1)$ denote the quality of specialized inputs produced by multinationals in country L relative to quality in country $\mathrm{H}$, we assume that the rent created by RSI is reduced by the fraction q. One could imagine that a less skilled workforce reduces the fraction of output that meets the exacting manufacturing tolerances of the blueprints created by RSI. Multinationals have access to the same technology as in country $\mathrm{H}$, but the lower technological level of country L further reduces the quality of manufacturing by firms of type $L$ by the fraction, $\lambda \in(0,1)$. Consequently, the 
rent per unit of output created by an investment $\mathrm{k}$ by suppliers of types $\mathrm{L}$ and $\mathrm{M}$ is given by:

$$
\mathrm{r}^{\mathrm{L}} \equiv \lambda \mathrm{q} \rho(\mathrm{z})(\mathrm{k}-\underline{\mathrm{k}})^{1 / 2}, \mathrm{r}^{\mathrm{M}} \equiv \mathrm{q} \rho(\mathrm{z})(\mathrm{k}-\underline{\mathrm{k}})^{1 / 2} \text {. }
$$

Suppliers from country L do not undertake FDI in country $\mathrm{H}$, since the fixed cost, F, would reduce their profits relative to suppliers of type $\mathrm{H}$. One could also suppose that multinationals with headquarters in country L would remain at a technological disadvantage.

In modelling contractual outsourcing, we assume that Nash bargaining takes place over the price that will be paid on delivery of the specialized input without the potential for lump-sum transfers. As a result, there is an efficiency loss due to prices that exceed marginal cost. This assumption captures an element of realism since pure-price contracts are the norm for international outsourcing between unrelated firms, perhaps because lump-sum transfers are difficult to enforce. ${ }^{8}$ Both RSI and the cost F of FDI are assumed to be non-contractible ${ }^{9}$, whereas the marginal costs of production in each country are contractible. Since the up-front costs of RSI create economies of scale, maximum profit is achieved when only one firm invests. Thus we assume that the assembler bargains with at most one supplier of each part. ${ }^{10}$

The subgame perfect equilibrium incorporates three stages of decision. At stage 1, potential contractual suppliers are formed in countries $\mathrm{L}$ and $\mathrm{H}$ with full awareness of the subsequent

\footnotetext{
${ }^{8}$ The fact that prices of inputs exceed marginal cost changes final-good output and the demand for parts, but not decisions taking output as given. The exclusion of lump-sum transfers is not crucial, since our main results either hold output fixed or are independent of endogenous changes in output.

${ }^{9}$ RSI involves unverifiable efforts in obtaining information about the needs of the assembler and ways to coordinate with other suppliers. It is difficult to verify F since it is incurred in a foreign country and may also include the cost of managerial effort.

${ }^{10}$ The possibility that the assembler bargains with two suppliers so as to increase competition is less important in this context because of the option of generic outsourcing. One could imagine that there are a large number of potential suppliers for each part $\mathrm{z}$, but that based on a random draw only one supplier in each country achieves the highest productivity in RSI as represented by $\rho(z)$. If more than one firm invests, then the assembler bargains with the supplier that would increase its profits the most. Since potential suppliers correctly anticipate this outcome, at most one firm will choose to invest for each part.
} 
equilibrium outcomes. Firms in country $\mathrm{H}$ decide whether to produce in country $\mathrm{H}(\mathrm{i}=\mathrm{H})$ or become a multinational by investing $\mathrm{F}$ to set up a plant in country L $(\mathrm{i}=\mathrm{M})$. At stage 2, each supplier chooses its profit-maximizing level of investment, which becomes sunk. If a firm decides not to invest, it exits and the part is later produced only as a generic. At stage 3 , the assembler engages in simultaneous Nash bargaining with suppliers of type $\mathrm{i}=\mathrm{H}, \mathrm{M} \mathrm{L}$ over the prices, denoted $\mathrm{p}^{\mathrm{i}}(\mathrm{z})$, of parts $z$. The assembler also commits to its output, $y$, at this stage. If bargaining is successful, the assembler orders y units of each part at the contracted price. Otherwise, the assembler buys y units of a generic version of the part at marginal cost from a spot market in country L.

\section{Purely domestic or purely international outsourcing.}

\section{A. Predictions of the model}

In this section we consider the possibility that contractual outsourcing involves purely domestic suppliers (type $\mathrm{i}=\mathrm{H}$ ) or, alternatively, purely foreign suppliers (type $\mathrm{i}=\mathrm{L}$ ) where each supplier undertakes both RSI and production in its own country. Letting $\mathrm{w}^{\mathrm{H}}(\mathrm{z})$ denote the (constant) marginal cost of production of part $\mathrm{z}$ in country $\mathrm{H}$ and $\mathrm{w}^{\mathrm{L}}(\mathrm{z})$ the (constant) marginal cost at which

the good can be produced in country $L$ and transported to country $H$, then $\delta \equiv w^{\mathrm{H}}(\mathrm{z})-\mathrm{w}^{\mathrm{L}}(\mathrm{z})>0$ represents the cost advantage of country L over country H. For simplicity we assume that $\delta$ is the same across all parts.

Since $\mathrm{k}^{\mathrm{i}}$ is sunk and not contractible, in Nash bargaining with an assembler of scale y in stage 3, a type i supplier of part $z$ would gain a surplus of $y\left[p^{i}(z)-w^{i}(z)\right]$ from a contract at a price $p^{i}(z)$. Taking into account the rent created by RSI, the marginal cost of part $\mathrm{z}$ to the assembler is then $\gamma^{\mathrm{i}}(\mathrm{z})$ $\equiv \mathrm{p}^{\mathrm{i}}(\mathrm{z})-\mathrm{r}^{\mathrm{i}}$. The threat point of the assembler if bargaining breaks down is to import the generic part at a marginal cost, $w^{\mathrm{L}}(\mathrm{z})$. Consequently, the assembler gains $y\left[w^{\mathrm{L}}(\mathrm{z})-\gamma^{\mathrm{i}}(\mathrm{z})\right]$ from agreement. 
Summing the gains of the assembler and supplier, the overall surplus from agreement is $\mathrm{y}\left[\mathrm{r}^{\mathrm{H}}-\delta\right]$ if the supplier is of type $\mathrm{H}$ and $\mathrm{yr}^{\mathrm{L}}$ if the supplier is of type L. Assuming that the parties have equal bargaining power and taking into account the cost of RSI, suppliers of types $\mathrm{H}$ and L respectively earn profit ${ }^{11}$ :

$$
\pi^{\mathrm{H}}=\mathrm{y}\left(\mathrm{r}^{\mathrm{H}}-\delta\right) / 2-\mathrm{k}^{\mathrm{H}} \text { and } \pi^{\mathrm{L}}=\mathrm{yr}^{\mathrm{L}} / 2-\mathrm{k}^{\mathrm{L}} \text {. }
$$

The corresponding gains of the assembler are $\mathrm{y}\left(\mathrm{r}^{\mathrm{H}}-\delta\right) / 2$ and $\mathrm{yr}^{\mathrm{L}} / 2$. Since $\mathrm{r}^{\mathrm{H}}-\delta>0$ and $\mathrm{r}^{\mathrm{L}}>0$, agreement is always reached for $\mathrm{k}^{\mathrm{i}}>\underline{\mathrm{k}}$. Otherwise, generic parts are imported.

For simplicity, we assume that the number of parts required for production is sufficiently large that a change in RSI level or in the location of production for just one part will have a very small effect on overall marginal cost, which is determined by the sum of the prices paid for parts. Since the effect on the assembler's choice of output is negligible, suppliers decide on their levels of RSI taking y as given. In stage 2, setting $k^{i}$ to maximize $\pi^{i}$ for $i=H, L$ as in (3) and using (1) and (2), we obtain:

$$
\begin{aligned}
& \mathrm{k}^{\mathrm{H}}=(\mathrm{y} \rho(\mathrm{z}) / 4)^{2}+\underline{\mathrm{k}}, \quad \mathrm{r}^{\mathrm{H}}=\mathrm{y}(\rho(\mathrm{z}))^{2} / 4 \\
& \mathrm{k}^{\mathrm{L}}=[\lambda \mathrm{qy} \rho(\mathrm{z}) / 4]^{2}+\underline{\mathrm{k}}, \quad \mathrm{r}^{\mathrm{L}}=(\lambda \mathrm{q})^{2} \mathrm{y}(\rho(\mathrm{z}))^{2} / 4 .
\end{aligned}
$$

Thus from (3) and (4), suppliers of type H and L earn profits

$$
\begin{aligned}
& \pi^{\mathrm{H}}=\pi^{\mathrm{H}}(\mathrm{z}, \mathrm{y})=(\mathrm{y} \rho(\mathrm{z}))^{2} / 16-\mathrm{y} \delta / 2-\underline{\mathrm{k}} \\
& \pi^{\mathrm{L}}=\pi^{\mathrm{L}}(\mathrm{z}, \mathrm{y})=(\lambda \mathrm{q})^{2}(\mathrm{y} \rho(\mathrm{z}))^{2} / 16-\underline{\mathrm{k}} .
\end{aligned}
$$

We assume that the assembler is the principal and hence the assembler's preferences dominate with respect to whether or not bargaining takes place with a particular type of supplier. In choosing between a type $\mathrm{H}$ and a type $\mathrm{L}$ supplier, the assembler is indifferent at part $\mathrm{z}=\mathrm{I}^{\mathrm{LH}}$ (I for

\footnotetext{
${ }^{11}$ Since $\mathrm{p}^{\mathrm{H}}(\mathrm{z})-\mathrm{w}^{\mathrm{H}}(\mathrm{z})=\mathrm{w}^{\mathrm{L}}(\mathrm{z})-\gamma^{\mathrm{H}}(\mathrm{z})=\left(\mathrm{r}^{\mathrm{H}}-\delta\right) / 2$ and $\mathrm{p}^{\mathrm{L}}(\mathrm{z})-\mathrm{w}^{\mathrm{L}}(\mathrm{z})=\mathrm{w}^{\mathrm{L}}(\mathrm{z})-\gamma^{\mathrm{L}}(\mathrm{z})=\mathrm{r}^{\mathrm{L}} / 2,(3)$ follows from $\pi^{\mathrm{i}}=\mathrm{y}\left(\mathrm{p}^{\mathrm{i}}(\mathrm{z})-\mathrm{w}^{\mathrm{i}}(\mathrm{z})\right)-\mathrm{k}^{\mathrm{i}}$.
} 
indifference) satisfying $\mathrm{r}^{\mathrm{H}}-\delta=\mathrm{r}^{\mathrm{L}}$, where, from (4),

$$
\rho\left(\mathrm{I}^{\mathrm{LH}}\right)=\left[4 \delta / \mathrm{y}\left(1-(\lambda q)^{2}\right)\right]^{1 / 2}
$$

Since $\mathrm{r}^{\mathrm{H}}-\delta \geq \mathrm{r}^{\mathrm{L}}$ for $\mathrm{z} \geq \mathrm{I}^{\mathrm{LH}}$, the assembler prefers contracts with type $\mathrm{H}$ suppliers for $\mathrm{z} \geq \mathrm{I}^{\mathrm{LH}}$ and type L suppliers for $\mathrm{z}<\mathrm{I}^{\mathrm{LH}}$. However suppliers must also be willing to invest. Letting part $\underline{\mathrm{H}}$ satisfy $\pi^{\mathrm{H}}(\underline{\mathrm{H}}, \mathrm{y})=0$ and part $\underline{\mathrm{L}}$ satisfy $\pi^{\mathrm{L}}(\underline{\mathrm{L}}, \mathrm{y})=0$, then, from (5) we obtain:

$$
\rho(\underline{\mathrm{H}})=4[\underline{\mathrm{k}}+\mathrm{y} \delta / 2]^{1 / 2} / \mathrm{y}, \quad \rho(\underline{\mathrm{L}})=4(\underline{\mathrm{k}})^{1 / 2} / \mathrm{y} \lambda \mathrm{q} .
$$

Thus a requirement for investment is $\mathrm{z} \geq \underline{\mathrm{H}}$ for type $\mathrm{H}$ suppliers and $\mathrm{z} \geq \underline{\mathrm{L}}$ for type $\mathrm{L}$.

It is notable from (5) that the profit of a type L supplier is independent of marginal cost, $\mathrm{w}^{\mathrm{L}}(\mathrm{z})$. Since $\mathrm{w}^{\mathrm{L}}(\mathrm{z})$ represents both the marginal cost of suppliers of type $\mathrm{L}$ and the marginal cost of suppliers of generic parts, the total surplus generated by a supplier of type $\mathrm{L}$ is simply the rent, $\mathrm{r}^{\mathrm{L}}$, generated by RSI. This surplus is shared equally between the parties by increasing the price, $\mathrm{p}^{\mathrm{L}}(\mathrm{z})$, to just offset any increase in $\mathrm{w}^{\mathrm{L}}(\mathrm{z})$. By contrast, the total surplus generated by an agreement with a supplier of type $\mathrm{H}$ is reduced by $\delta$, due to the threat point of importing generic parts. Consequently, as shown by (7), an increase in $\delta$ raises $\underline{\mathrm{H}}$, so as to reduce the entry of suppliers of type $\mathrm{H}$, but $\delta$ has no effect on the part $\mathrm{z}=\underline{\mathrm{L}}$ at which a supplier of type $\mathrm{L}$ is just willing to produce.

Proposition 1 (see Appendix A for the proof) sets out the conditions that determine the choice of organizational form. To express these conditions, we define $\beta^{\lambda q} \equiv(\lambda q)^{2} /\left(1-(\lambda q)^{2}\right)$ for $\lambda q$ $<1$, which is increasing in $\lambda q$ as the quality of manufacturing of suppliers of type $L$ improves. If $\lambda q$ is sufficiently close to 1 , then suppliers of type $\mathrm{L}$ would drive out suppliers of type $\mathrm{H}$ due to the lower wage in L. To focus on internal solutions, we assume $\rho\left(\mathrm{I}^{\mathrm{LH}}\right)<1, \rho(\underline{\mathrm{L}})<1$ and $\rho(\underline{\mathrm{H}})<1$, which require ${ }^{12}$ :

\footnotetext{
${ }^{12}$ From (6) and (7), 16k/ $/(\mathrm{y})^{2}<(\lambda \mathrm{q})^{2}<1-4 \delta / \mathrm{y}$.
} 


$$
16 \underline{\mathrm{k}} /\left[(\mathrm{y})^{2}-16 \underline{\mathrm{k}}\right]<\beta^{\lambda \mathrm{q}}<\mathrm{y} / 4 \delta-1 \text { and } \underline{\mathrm{k}} / \mathrm{y} \delta<\mathrm{y} / 16 \delta-1 / 2 .
$$

Proposition 1: Assume (8).

(A) If $\underline{k} y \delta \geq \beta^{\lambda q} / 2$ then $I^{L H}<\underline{H} \leq \underline{L}$ and contractual outsourcing is restricted to purely domestic type $H$ suppliers in the high-wage country. The assembler contracts with $H$ for parts, $\mathrm{z} \in[\underline{H}$, Ž], with higher productivity of RSI and imports generic parts $z \in[0, \underline{H})$.

(B) If $\underline{k} y \delta<\beta^{\lambda q} / 2$, then a range of parts with the highest productivity of RSI are produced domestically in the high-wage country through contractual outsourcing to suppliers of type $H$, whereas a range of parts with the next highest productivity level of RSI are imported from the lowwage country through contractual outsourcing to suppliers of type L. The remaining parts are imported as generics. There are two subcases:

(i) If $\left(\beta^{\lambda q}-1\right) / 4 \leq \underline{k} y y \delta<\beta^{\lambda q} / 2$, then $\underline{L}<\underline{H}$ and $I^{L H} \leq \underline{H}$. The assembler contracts with $H$ for parts $\mathrm{Z} \in[\underline{\mathrm{H}}, \check{Z}]$, with $L$ for parts $\mathrm{z} \in[\underline{\mathrm{L}}, \underline{H})$ and imports generic parts $\mathrm{z} \in[0, \underline{L})$.

(ii) If $\underline{k} / y \delta<\left(\beta^{\lambda q}-1\right) / 4$ then $\beta^{\lambda q}>1$ and $\underline{L}<\underline{H}<I^{L H}$. The assembler contracts with $H$ for parts $z$ $\in\left[I^{L H}, \check{Z}\right]$, and with $L$ for parts $\mathrm{z} \in\left[\underline{L}, I^{L H}\right)$ and imports generic parts $\mathrm{z} \in[0, \underline{L})$.

As Proposition 1 shows, the value of the minimum investment, $\underline{\mathrm{k}}$, required for RSI relative to the cost savings, $\delta y$, from production in the low-wage country $\mathrm{L}$ is critical for determining the range of parts produced by each type of supplier. A high value of $\underline{k} / \mathrm{y} \delta$ acts as a barrier to entry for suppliers of type L, particularly for parts with a low productivity of RSI due to a low $\rho(\mathrm{z})$. From Proposition 1(A), if $\underline{\mathrm{k}} / \mathrm{y} \delta \geq \beta^{\lambda \mathrm{q} / 2}$, then $\underline{\mathrm{H}} \leq \underline{\mathrm{L}}$, which implies that it is profitable for type $\mathrm{L}$ to produce only the parts with high productivity of RSI that type H suppliers also find profitable. Since $\mathrm{I}^{\mathrm{LH}}<$ $\underline{\mathrm{H}}$, the assembler prefers a contract with type $\mathrm{H}$ over type $\mathrm{L}$ with the result that imports are limited to generic parts with low productivity of RSI. 
Alternatively, if $\underline{k} / \mathrm{y} \delta<\beta^{\lambda q} / 2$, as in Proposition 1(B), then $\underline{\underline{L}}<\underline{\mathrm{H}}$, reflecting the greater ease of entry of type L suppliers. The assembler engages in both international and domestic contractual outsourcing, but parts with the highest productivity of RSI are produced at home. There are two sub-cases. For $\left(\beta^{\lambda q}-1\right) / 4<\underline{\mathrm{k}} / \mathrm{y} \delta<\beta^{\lambda q} / 2$, we show in $\mathrm{B}(\mathrm{i})$ that the assembler prefers type $\mathrm{H}$ suppliers if they are willing to enter $\left(\mathrm{I}^{\mathrm{LH}}<\underline{\mathrm{H}}\right)$ and hence type $\mathrm{L}$ suppliers gain contracts only for the parts, $\mathrm{z}$ $\in[\underline{\mathrm{L}}, \underline{\mathrm{H}})$, with lower productivity of RSI that type $\mathrm{H}$ suppliers are not willing to produce. The case $\underline{\mathrm{k}} / \mathrm{y} \delta<\beta^{\lambda \mathrm{a}}-1$, examined in $\mathrm{B}(\mathrm{ii})$, is a possibility only if type $\mathrm{L}$ and type $\mathrm{H}$ suppliers are sufficiently similar in terms of quality of manufacturing that $\beta^{\lambda q}>1$. This similarity means that the assembler tends to favor low-cost suppliers of type $\mathrm{L}\left(\underline{\mathrm{H}}<\mathrm{I}^{\mathrm{LH}}\right)$. Thus type $\mathrm{L}$ suppliers gain contracts for parts $\mathrm{z} \in\left[\underline{\mathrm{H}}, \mathrm{I}^{\mathrm{LH}}\right.$ ) that type $\mathrm{H}$ would like to produce. Contracts are awarded to type $\mathrm{H}$ for $\mathrm{z} \geq \mathrm{I}^{\mathrm{LH}}$ and to type $\mathrm{L}$ for $\mathrm{z} \in\left[\underline{\mathrm{L}}, \mathrm{I}^{\mathrm{LH}}\right)$. Again, generic parts are imported for $\mathrm{z}<\underline{\mathrm{L}}$.

\section{B. Comparative static effects}

In our empirical analysis we are able to measure international contractual outsourcing, but not contractual outsourcing at home, so henceforth we assume $\underline{\mathrm{L}}<\underline{\mathrm{H}}$ to ensure that there is some contractual outsourcing to firms in country L. From Proposition 1, this requires $\underline{\mathrm{k}} / \mathrm{y} \delta<\beta^{\lambda \mathrm{q}} / 2$ so as to rule out case (A) in which contractual outsourcing is restricted to country H. Of primary interest for the empirical analysis is the effect of trade costs as measured by the distance between the various outsourcing locations and destination countries. Since $w^{\mathrm{L}}(\mathrm{z})$ includes the cost of transport to country $\mathrm{H}$, a reduction in trade costs would increase the cost advantage, $\delta$, of the low-wage country. We are also interested in the effects of an improvement in the quality of manufacturing in country L, as represented by an increase in q. In addition, we consider the effects of variations in the scale, y, of the assembler. Corollary 1 sets out the relevant comparative static effects. 
Corollary 1. Assume $\underline{L}<\underline{H}$ and (8).

(A) An increase in scale, $y$, of the assembler reduces $\underline{L}, \underline{H}$ and $I^{L H}$, and hence reduces the range of generic exports from country $L$ and raises the range of parts produced under contractual outsourcing in country $H$.

(B) Hold y fixed.(i) An increase in the cost advantage $\delta$, has no effect on $\underline{L}$, but $\underline{H}$ and $I^{L H}$ increase. Thus the range of contractual exports from country L rises at the expense of contractual outsourcing in country $H$. The range of generic exports is unchanged (ii) An improvement in quality, q, reduces $\underline{L}$, has no effect on $\underline{H}$, but increases $I^{L H}$. Thus the range of contractual exports from country $L$ is increased at the expense of generic exports. If $\underline{k} / y \delta<\left(\beta^{\lambda q}-1\right) / 4$, then $\underline{H}<I^{L H}$ and the reduction in the assembler's preference for type $H$ suppliers arising from the increase in $I^{L H}$, narrows the range of parts produced through contractual outsourcing in country $H$.

Proof: The proof of Corollary 1 follows directly from the expressions for $\underline{L}, \underline{H}$ and $I^{\mathrm{LH}}$ in (6) and (7) and Proposition 1.

Corollary 1(B) provides us with the following testable hypotheses: ${ }^{13}$

(I) An increase in the cost advantage $\delta$ of the low-wage country raises its range of contractual exports, with no impact on its range of generic exports;

(II) An increase in the quality q of the foreign workforce raises its range of contractual exports, and lowers its range of generic exports.

We test these hypotheses by constructing measures of the range of contractual and generic exports from Chinese provinces to destination countries, and examining the impact of differences

\footnotetext{
${ }^{13}$ Corollary 1 refers to effects on the range of exports, which are our primary focus of interest. Predictions as to the volume of exports may differ. For example, an increase in scale reduces the range of generic imports, but since the volume increases, the effect on the value of generic exports is ambiguous.
} 
in the provinces' cost advantage (due to proximity to the destination countries) and workforce quality. Before turning to these empirical tests, we should note one potential difficulty: hypotheses (I) and (II) are derived holding the scale of the assembler, y, fixed, but in principle this scale is endogenous because it depends on the assembler's marginal cost. Marginal cost is determined by adding up the assembler's net marginal cost for each part, which in turn depends on the range of parts covered by each organizational form. If a change in a parameter leads to a shift in organizational form that reduces marginal cost, then we would expect the output of the assembler to rise (given demand). ${ }^{14}$ But with an increase in y, Corollary 1(A) states that the range of generic exports from the low-wage country are reduced, with an ambiguous impact on its range of contractual exports, which therefore modifies hypotheses (I) and (II).

Fortunately, the ambiguity arising from endogenous changes in the scale of output (which we cannot control for empirically) can be resolved. Instead of focussing on the absolute range of contractual or generic exports from the low-wage country, we consider their relative magnitude, i.e. the proportion of exported varieties that are contractual rather than generic. As shown in Corollary 2, this approach allows us to vary the scale of output y endogenously, and still obtain definite predictions about how the cost advantage $\delta$, and quality q, affect the relative range of products produced through contractual versus generic outsourcing.

Corollary 2. Assume $\underline{L}<\underline{H}$ and (8).

Let $\omega$ denote the proportion of exported varieties from country $L$ that are of the contractual rather than generic type. Then $\omega$ is increasing in (i) the scale, $y$, of the assembler, (ii) the cost advantage,

\footnotetext{
${ }^{14}$ See Spencer and Qiu(2001) for an analysis of the feedback effects between marginal cost, output and RSI for the case in which only type H suppliers undertake RSI.
} 
$\delta$, of country $L$ and (iii) the quality $q$, of manufacturing in country $L$.

Proof: The results follow from $\omega \equiv 1-\rho(\underline{L}) / \rho(\underline{H})=1-(\underline{k})^{1 / 2} / \lambda q(\underline{k}+y \delta / 2)^{1 / 2}$ for $\left(\beta^{\lambda q}-1\right) / 4 \leq \underline{k} / y \delta<$ $\beta^{\lambda q} / 2$, and $\omega \equiv 1-\rho(\underline{L}) / \rho\left(I^{L H}\right)=1-(\underline{k} / y \delta)^{1 / 2} / \beta^{\lambda q}$ for $\underline{k} / y \delta<\left(\beta^{\lambda q}-1\right) / 4$, so d $\omega / d y>0, \partial \omega / \partial \delta>0$ and $\partial \omega / \partial q>0$.

This Corollary leads to our third testable hypothesis:

(III) An increase in the cost-advantage of the low-wage country or the quality of its workforce (with any induced increase in assembler scale) raises the proportion of exported varieties from country $\mathrm{L}$ that are contractual rather than generic.

In our empirical work we will examine hypotheses (I) and (II) using separate regressions where the dependent variables are the range of contractual versus generic exports, respectively. Because these two hypotheses hold assembler scale constant, we should not necessarily expect the hypotheses to apply as stated. But the weaker hypothesis (III), which involves a comparison of the two regressions, should hold even with endogenous changes in the scale of the assembler.

\section{Estimation}

To test these comparative statics effects we make use of a dataset on Chinese exports by province to all destination countries. ${ }^{15}$ Chinese exports are distinguished by whether they are “ordinary” versus "processing” exports. The latter category is composed of goods for which parts are initially imported duty-free; used in China; and the finished good must then be exported (since no duties were paid on the parts, it cannot be sold domestically). By its very nature, we can expect that processing trade is done under contract with some foreign buyer. However, the same categories

15 Data sources are described in Appendix B. 
of final goods can instead be purchased as “ordinary” exports, which does not involve any prior agreement between buyer and seller as to the imported parts, methods of assembly, etc. Therefore, we identify Chinese processing exports as resulting from contractual outsourcing, and Chinese ordinary exports as what we have called generic outsourcing.

Our primary interest is in the ranges of goods exported by the low-wage country: these ranges are given in our theory by $[0, \underline{\mathrm{L}})$ for generic outsourcing and $[\underline{\mathrm{L}}, \underline{\mathrm{H}})$ or $\left[\underline{\mathrm{L}}, \mathrm{I}^{\mathrm{LH}}\right)$ for contractual outsourcing. (We do not attempt to measure outsourcing within the high-wage country). In order to measure the ranges of goods empirically, we appeal to the “extensive margin” recently used by Hummels and Klenow (2005). To define this, let $I_{t}^{j k} \subset\{1, \ldots, N\}$ denote the set of goods exported by province j of China to destination county k, in year t and $I_{t}^{*} \equiv \bigcup_{j, k} I_{t}^{j k}$ denote the total set of goods exported by China. Also, let $x_{i t}^{*}, i \in I_{t}^{*}$ denote the total exports of good i from China to the world in year $\mathrm{t}$ and $\mathrm{x}^{*}{ }_{t}$ total exports from China. With this notation, the extensive margin of province $\mathrm{j}$ to country $\mathrm{k}$ in year $\mathrm{t}$ is defined by:

$$
E M_{t}^{j k} \equiv \frac{\sum_{i \in I_{t}^{j k}} x_{i t}^{*}}{\sum_{i \in I_{t}^{*}} x_{i t}^{*}}=\frac{\sum_{i \in I_{t}^{j k}} x_{i t}^{*}}{x_{t}^{*}}
$$

Feenstra (1994) shows how this type of formula can be obtained from an underlying CES aggregator function, and represents the theoretically appropriate way to measure product variety in a CES framework. Notice that the numerator and denominator of (9) differ only by the set of goods over which the summation is taken: in the numerator, the summation is taken over the set of goods exported by province $\mathrm{j}$ to country $\mathrm{k}$, whereas in the denominator the summation if taken over all goods exported by China in year t. Therefore, the variation in (9) across provinces and destination countries represents differences in the product varieties traded between them, and not the value of 
exports.

Letting $x_{i t}^{j k}, i \in I_{t}^{j k}$ represent the value of exports of good i from province $\mathrm{j}$ to country $\mathrm{k}$ in year t, where $x_{t}^{j k} \equiv \sum_{i \in I_{t}^{j k}} x_{i t}^{j k}$, Hummels and Klenow (2005) further propose the following formula for the intensive margin of exports between region $\mathrm{j}$ and country $\mathrm{k}$ :

$$
I M_{t}^{j k} \equiv \frac{\sum_{i \in I_{t}^{j k}} x_{i t}^{j k}}{\sum_{i \in I_{t}^{j k}} x_{i t}^{*}}=\frac{x_{t}^{j k}}{\sum_{i \in I_{t}^{j k}} x_{i t}^{*}}
$$

Notice that the difference between the numerator and denominator of (10) comes from the value of exports: in the numerator it is the exports from province $\mathrm{j}$ to country $\mathrm{k}$, summed over goods $i \in I_{t}^{j k}$, whereas in the denominator it is total Chinese exports, summed over the same set $i \in I_{t}^{j k}$. In this sense, the intensive margin measures the amount exported by each province to each country, relative to the country total. By multiplying the extensive and intensive margins we obtain exports from province $\mathrm{j}$ to country $\mathrm{k}$, relative to Chinese total exports:

$$
E M_{t}^{j k} \times I M_{t}^{j k}=\frac{x_{t}^{j k}}{x_{t}^{*}} .
$$

Thus, the extensive and intensive margins are a decomposition of the exports from each province to each country into their variety and volume components, respectively.

Estimates of a gravity equation using the extensive margin as the dependent variable are shown in Table 1. (For comparison, in Appendix Table C1, we also report the estimates obtained using the intensive margin as a dependent variable.) The regressions in the top half of Table 1 use the extensive margin constructed from ordinary exports as the dependent variable, while the regressions in the bottom half of Table 1 use the extensive margin constructed from processing exports as the dependent variable. In each case, we have annual data on Chinese exports from 1988- 
2000, but for brevity just report the regressions at 3-year intervals. The regressors include GDP per capita as well as the average manufacturing wage in the source province: these are treated as endogenous, and as instruments we use the fraction of the population with primary, junior, senior and university education. Next, we include GDP per capita in the destination country as well as population in the source provinces and destination countries. In addition, we use two measures of distance: the internal distance from the province to the nearest shipping port or major border crossing; and then the external distance from that port/border crossing to the destination country. Both of these will measure transportation costs, with provinces that are closer to their destination markets have a cost advantage over more distant provinces.

Our primary interest is in the effect of distance on the extensive margins. The theoretical hypothesis (I) is that distance should impact the range of contractual outsourcing, i.e. the extensive margin of processing exports, but not impact the range of generic outsourcing, i.e. the extensive margin of ordinary exports. From Table 1, we see that external distance has no significant impact on the extensive margin of either ordinary or processing exports, but that internal distance affect both extensive margins. However, consistent with hypothesis (III), internal distance has a substantially greater negative impact on processing exports as compared to ordinary exports: in 2000, greater internal distance reduces the range of processing exports by a factor of 10 times more than it reduces ordinary exports. We take these estimates as providing support for our hypothesis that the range of processing exports is more sensitive to distance than are generic exports, at least for internal distance from the province to the nearest port/border crossing.

A second hypothesis is that a higher quality workforce in the source province will contribute to a greater range of processing exports. Recall that we have used the education level of the population as instruments for the manufacturing wage (and also for the GDP per capital of the 
province). We therefore interpret the manufacturing wage as a measure of workers quality rather than labor cost. In Table 1, we see that the manufacturing wage has a negative coefficient for ordinary exports, consistent with hypothesis (II), and either a positive or near-zero and insignificant coefficient for processing exports. These results are not as clean as what we obtain for distance, but still offer significant support for hypothesis (II).

In Table 2 we repeat the regressions from Table 1, but now weight them by the volume of trade from each province to each destination country. That is, we use the predicted intensive margins (from the regression reported in Table A1) as weights. The results in Table 2 for the distance variables are similar to those in the unweighted regressions of Table 1: internal distance has a much greater negative impact on the range of processing exports than ordinary exports, confirming hypothesis (III) with respect to cost advantages due to distance. In Table 2, the manufacturing wage is now positive and significant (for 1994 - 2000) for the range of processing exports, and negative and significant (for several years) for ordinary exports. These results offer more support for hypothesis (II), that a higher quality workforce results in a greater range of contractual outsourcing (processing exports) at the expense of generic outsourcing (ordinary exports).

Two control variables are related to the size of the destination countries - their GDP per capita and populations - which might have captured the scale of the assembler. However, it turns out that both these variables are highly insignificant, so we are not controlling for that variable. Instead, our regression indicates that there is a scale effect of the source province: an increase in the provincial population has a much greater positive effect on the range of processing exports than ordinary exports, especially in more recent years. This finding suggests to us that an expanded model with free entry of assemblers might be appropriate, whereby larger provinces can support the outsourcing requirements of a greater number of foreign assemblers, especially for contractual 
outsourcing. That empirical prediction is beyond the scope of the model in this paper, however.

\section{Outsourcing production via FDI}

\section{A: Predictions of the model}

This section adds the possibility of contractual outsourcing to multinational suppliers of type M that undertake RSI in country $\mathrm{H}$, but set up a wholly owned subsidiary to manufacture the parts in country L. Compared with type $\mathrm{H}$ suppliers, multinationals benefit from the lower wage in country L, but they must pay the fixed cost, F, to set up a plant, and the lower quality of manufacturing in country L reduces the rent created by RSI (see (2)). Type L suppliers have an even lower quality of manufacturing due to inferior technology, but they are not subject to the fixed cost.

More formally, type M suppliers earn profit, given by $\pi^{\mathrm{M}}=\mathrm{y}\left[\mathrm{p}^{\mathrm{M}}(\mathrm{z})-\mathrm{w}^{\mathrm{L}}(\mathrm{z})\right]-\mathrm{k}^{\mathrm{M}}-\mathrm{F}$, where $\mathrm{p}^{\mathrm{M}}(\mathrm{z})$ is the price of the product determined by Nash bargaining with the assembler at stage 3 . Since both $\mathrm{k}^{\mathrm{M}}$ and $\mathrm{F}$ are not contractible, it follows, analogous to the previous bargaining outcomes (see (3)), that $\pi^{\mathrm{M}}=\mathrm{yr}^{\mathrm{M}} / 2-\mathrm{k}^{\mathrm{M}}-\mathrm{F}$, where $\mathrm{r}^{\mathrm{M}} \equiv \mathrm{q} \rho(\mathrm{z})\left(\mathrm{k}^{\mathrm{M}}-\underline{\mathrm{k}}\right)^{1 / 2}$ from (2). The assembler gains $\mathrm{yr}^{\mathrm{M}} / 2$. From profit maximization at stage 2 , we obtain

$$
\mathrm{k}^{\mathrm{M}}=(\mathrm{yq} \rho(\mathrm{z}))^{2} / 16+\underline{\mathrm{k}}, \mathrm{r}^{\mathrm{M}}=\mathrm{y}(\mathrm{q} \rho(\mathrm{z}))^{2} / 4 .
$$

Consequently, we can express the stage 1 profit of a multinational as:

$$
\pi^{\mathrm{M}}=\pi^{\mathrm{M}}(\mathrm{z}, \mathrm{y}, \mathrm{F})=(\mathrm{yq} \rho(\mathrm{z}))^{2} / 16-\underline{\mathrm{k}}-\mathrm{F} .
$$

As (13) shows, just as for contractual suppliers from country L, the profits of multinationals from contractual production in $\mathrm{L}$ do not depend on the marginal cost, $\mathrm{w}^{\mathrm{L}}(\mathrm{z})$.

Setting $\mathrm{r}^{\mathrm{H}}-\delta=\mathrm{r}^{\mathrm{M}}$ to define part $\mathrm{z}=\mathrm{I}^{\mathrm{MH}}$, the assembler prefers a type $\mathrm{H}$ rather than a type $\mathrm{M}$ supplier if and only if $\mathrm{z} \geq \mathrm{I}^{\mathrm{MH}}$ where, letting $\beta^{\mathrm{q}} \equiv(\mathrm{q})^{2} /\left(1-(\mathrm{q})^{2}\right)$ and using (12) and (4), we obtain

$$
\rho\left(\mathrm{I}^{\mathrm{MH}}\right)=\left[4 \delta / \mathrm{y}\left(1-(\mathrm{q})^{2}\right)\right]^{1 / 2}=\left[4 \delta\left(1+\beta^{\mathrm{q}}\right) / \mathrm{y}\right]^{1 / 2} .
$$


However, the assembler always prefers type $\mathrm{M}$ to type $\mathrm{L}$ due to type M's greater creation of rent ${ }^{16}$. Letting $\mathrm{z}=\underline{\mathrm{M}}$ satisfy $\pi^{\mathrm{M}}(\underline{\mathrm{M}}, \mathrm{y}, \mathrm{F})=0$, investment by multinationals is profitable only if $\mathrm{z} \geq \underline{\mathrm{M}}$, where

$$
\rho(\underline{\mathrm{M}})=4(\underline{\mathrm{k}}+\mathrm{F})^{1 / 2} / \mathrm{yq} \text {. }
$$

Proposition 2 (see Appendix A for the proof) describes the various outcomes with respect to the choice of supplier. To reduce the number of cases, we restrict attention to $F / y \delta \leq 1 / 4$ in Proposition 2A, which implies that the fixed cost of FDI is at most one quarter of the savings, yo, from the lower wage in country L. With fixed costs in this lower range, there is a closer correspondence between the assembler's preference for type M suppliers and their availability. ${ }^{17}$ As Proposition 2(A) shows, if $\mathrm{F} / \mathrm{y} \delta \leq 1 / 4$ and $\underline{\mathrm{H}} \leq \underline{\mathrm{M}}$, then the assembler prefers $\mathrm{H}$ over $\mathrm{M}$ for $\mathrm{z} \geq \underline{\mathrm{H}}$ (due to $\mathrm{I}^{\mathrm{MH}} \leq \underline{\mathrm{H}}$ ). In this case, type $\mathrm{H}$ suppliers drive out type $\mathrm{M}$ suppliers and the possibilities with respect to contractual and generic outsourcing are described by Proposition 1, parts (A) and (B)(i). ${ }^{18}$ Proposition 2(B) then develops the various cases that arise when some parts are supplied by multinationals. In part B(i), we compare type $\mathrm{H}$ with type $\mathrm{M}$ suppliers, whereas in B(ii), we compare type $\mathrm{M}$ with type $\mathrm{L}$ suppliers and also consider the potential for generic imports. Again to focus on internal solutions, we assume $\rho\left(\mathrm{I}^{\mathrm{MH}}\right)<1$ and $\rho(\underline{\mathrm{M}})<1$ which require ${ }^{19}$ :

$$
16(\underline{k}+F) /\left[(y)^{2}-16(\underline{k}+F)\right]<\beta^{9}<y / 4 \delta-1 .
$$

\footnotetext{
${ }^{16}$ From (12) and (4), $\mathrm{r}^{\mathrm{L}}=(\lambda){ }^{2} \mathrm{r}^{\mathrm{M}}$ where $\lambda<1$.
}

${ }^{17}$ The assumption $\mathrm{F} / \mathrm{y} \delta \leq 1 / 4$ rules out $\underline{\mathrm{H}}<\underline{\mathrm{M}}<\mathrm{I}^{\mathrm{MH}}$ in which the assembler contracts with $\mathrm{H}$ for $\mathrm{z}$ $\in[\underline{\mathrm{H}}, \underline{\mathrm{M}})$ (type $\mathrm{M}$ is not available), with $\mathrm{M}$ for $\mathrm{z} \in\left[\underline{\mathrm{M}}, \mathrm{I}^{\mathrm{MH}}\right.$ ) and again with $\mathrm{H}$ for $\mathrm{z} \geq \mathrm{I}^{\mathrm{MH}}$.

${ }^{18}$ The possibility $\underline{\mathrm{L}}<\underline{\mathrm{H}}<\mathrm{I}^{\mathrm{LH}}$ in Proposition 1 part (B)(ii) is ruled out since if the assembler prefers suppliers of type $\mathrm{H}$ whenever $\mathrm{M}$ would enter (i.e. $\mathrm{I}^{\mathrm{MH}}<\underline{\mathrm{M}}$ ), then the assembler also prefers $\mathrm{H}$ to $\mathrm{L}$ whenever $\mathrm{L}$ would enter (i.e. $\mathrm{I}^{\mathrm{LH}}<\underline{\mathrm{L}}$ ).

${ }^{19}$ We use (14) and (15) to obtain $16(\underline{\mathrm{k}}+\mathrm{F}) /(\mathrm{y})^{2}<(\mathrm{q})^{2}<1-4 \delta / \mathrm{y}$. 
Proposition 2 Assume (8) and (16).

(A) If $\left(\beta^{q} / 2-\underline{k} / y \delta\right) /\left(1+\beta^{q}\right) \leq F / y \delta \leq 1 / 4$, then $I^{M H} \leq \underline{H} \leq \underline{M}$ and $I^{L H} \leq \underline{H}$. Purely domestic suppliers of type $H$ drive out multinationals and Proposition 1, parts (A) and (B)(i) apply.

(B) Suppose $F / y \delta<\left(\beta^{q} / 2-\underline{k} / y \delta\right) /\left(1+\beta^{q}\right)$, which requires $\underline{k} / y \delta<\beta^{q} / 2$.

(i) Parts with the highest productivity of RSI are produced through domestic contractual outsourcing to suppliers of type $H$, whereas parts with the next highest productivity level are contracted to multinationals of type $M$ that export from country L. (a) If $\underline{k} y \delta \geq\left(\beta^{q}-1\right) / 4$, then $\underline{M}<\underline{H}$ and $I^{M H}<$ $\underline{H}$. The assembler contracts with $H$ for $\mathrm{z} \in[\underline{\mathrm{H}}, \check{Z}]$ and with $M$ for $\mathrm{z} \in[\underline{\mathrm{M}}, \underline{\mathrm{H}})$. (b) If $\underline{\mathrm{k}} / y \delta<\left(\beta^{q}-1\right) / 4$, then $\underline{M}<\underline{H}<I^{M H}$. The assembler contracts with $H$ for $\mathrm{z} \in\left[I^{\mathrm{MH}}, \breve{Z}\right]$ and with $M$ for $\mathrm{z} \in\left[\underline{M}, I^{\mathrm{MH}}\right)$.

(ii) Purely domestic (type L) suppliers in country L gain contracts only for lower productivity parts that multinationals (type $M$ ) are not willing to produce. If $F / \underline{k}>1 / \beta^{\lambda}$, then $\underline{L}<\underline{M}$. The assembler contracts with type $L$ for $\mathrm{z} \in[\underline{L}, \underline{M})$ and imports generic parts for $\mathrm{z} \in[0, L)$.

As B(i) of Proposition 2 demonstrates, parts with the highest productivity of RSI are produced at home through contractual outsourcing in country $\mathrm{H}$, whereas parts with the next highest productivity are produced through contractual outsourcing to multinationals of type $\mathrm{M}$ that undertake RSI in country H, but produce in L through FDI. Turning to B(ii), we show that if F/ $\underline{k}>$ $1 / \beta^{\lambda}$ where $\beta^{\lambda} \equiv(\lambda)^{2} /\left(1-(\lambda)^{2}\right)$, suppliers of type $L$ receive contracts for a range of parts in which the productivity of RSI is further reduced. Because of the higher quality of manufacturing, the assembler always prefers a type $\mathrm{M}$ over a type $\mathrm{L}$ supplier. Consequently, there is a role for contracting with suppliers of type $\mathrm{L}$ only for the range of parts $\mathrm{z} \in[\underline{\mathrm{L}}, \underline{\mathrm{M}})$, where the fixed cost, $\mathrm{F}$, is sufficiently high to prevent the entry of $M$. If $F / \underline{k} \leq 1 / \beta^{\lambda}$, then $M$ drives out $L$. At the lowest levels of productivity of RSI, only generic parts are exported from country L. 
Figure 3 (introduced in Section 2) illustrates the ranking of suppliers with respect to the productivity of RSI: the most productive firms are type H suppliers (i.e. domestic outsourcing); followed by type M suppliers (multinationals); followed by type L suppliers (foreign outsourcing); followed by generic suppliers of intermediate inputs on the spot market in country L. This type of ranking is similar in spirit to that obtained by Antràs and Helpman (2004) (see also the survey by Helpman, 2005), except that firms in their framework differ in their marginal cost of production. In our framework, by contrast, firms differ in the productivity of RSI.

\section{B. Comparative static effects}

In Corollary 3, we extend Proposition 2 to examine the effects of the parameters, $y, \delta$ and q, taking into account the option that the assembler in country $\mathrm{H}$ may contract with a multinational supplier of type M producing in the low-wage country. We restrict attention to the cases satisfying $\underline{\mathrm{L}}<\underline{\mathrm{M}}<\underline{\mathrm{H}}$ so as to ensure that contractual exporting involves both type $\mathrm{L}$ and type $\mathrm{M}$ suppliers. ${ }^{20}$

Corollary 3. Assume $\underline{L}<\underline{M}<\underline{H}$, (8) and (16).

(A) An increase in output, $y$, reduces $\underline{L}, \underline{M}, \underline{H}$, and $I^{M H}$ and hence reduces the range of generic exports from country $L$ and raises the range of parts produced under contractual outsourcing in country $H$. Since $\underline{M}$ falls by more than $\underline{L}$, fewer varieties are exported by suppliers of type L.

(B) Hold y fixed. (i) An increase in the cost advantage, $\delta$, has no effect on $\underline{L}$ or $\underline{M}$, but $\underline{H}$ and $I^{M H}$ are increased, with the result that the range of parts exported from country $L$ by multinationals is increased at the expense of contractual outsourcing in country $H$. There is no change in the range of parts exported by contractual suppliers of type L or exported as generics. (ii) An improvement in the quality, $q$, of manufacturing in country $L$ reduces $\underline{L}$ and $\underline{M}$, but $H$ is unchanged and $I^{M H}$ rises.

\footnotetext{
${ }^{20}$ From Proposition 3, $\underline{\mathrm{L}}<\underline{\mathrm{M}}<\underline{\mathrm{H}}$ iff $\mathrm{F} / \mathrm{y} \delta<1 / 4, \mathrm{~F} / \mathrm{y} \delta<\left(\beta^{\mathrm{q}} / 2-\underline{\mathrm{k}} / \mathrm{y} \delta\right) /\left(1+\beta^{\mathrm{q}}\right)$ and $\mathrm{F} / \underline{\mathrm{k}}>1 / \beta^{\lambda}$.
} 
There is an increase in the range of contractual exports from country $L$ due to an increase in the range of parts exported by multinationals and a reduction in the range of generic exports. Since $\underline{M}$ falls by more than $\underline{L}$, fewer varieties are exported by suppliers of type $L$. If $k / y \delta<\left(\beta^{\lambda q}-1\right) / 4$, then the fall in the assembler's preference for type $H$ suppliers narrows the range of parts produced through domestic contractual outsourcing.

Proof: (A) If $\underline{L}<\underline{M}$, then $d \rho(\underline{M}) / d y=-\rho(\underline{M}) / y<d \rho(\underline{L}) / d y=-\rho(\underline{L}) / y$ and hence that the range of parts produced by $\mathrm{M}$ expands more than the range of parts produced by $\mathrm{L}$. The remaining results in (A) and (B) follow directly from the expressions for $\underline{\mathrm{L}}, \underline{\mathrm{M}}, \underline{\mathrm{H}}, \mathrm{I}^{\mathrm{MH}}$ (see (7), (14) and (15)) and Proposition 2.

Part (B) of this Corollary leads to the following hypotheses:

$\left(\mathrm{I}^{\prime}\right)$ Increases in the cost advantage $\delta$ of the low-wage country raises its range of contractual exports made by multinationals, with no change on the range of contractual exports made by unaffiliated firms or in the range of generic exports;

(II') Increases in the quality q of the foreign workforce raises the range of contractual exports by multinationals, and lowers the range of contractual exports by unaffiliated firms and the range of generic exports.

Similar to hypotheses (I) and (II), hypotheses (I') and (II') are derived while holding constant the scale of the assembler, y, but in principle this scale can change. So we next state an extension that allows for the endogenous increase in scale, $y$, due to a rise in cost advantage or workforce quality in the low-wage country. In this result we define $\psi^{\mathrm{M}}$ and $\psi^{\mathrm{L}}$ to represent the proportion of varieties that are exported by contractual suppliers of type $M$ and $L$ respectively. The sum, $\psi^{\mathrm{M}}+\psi^{\mathrm{L}}$, analogous to $\omega$ in Corollary 2, represents the proportion of exported varieties that are of the 
contractual rather than the generic type:

Corollary 4. Assume $\underline{L}<\underline{M}<\underline{H}$, (8) and (16).

In response to an increase in the cost advantage, $\delta$, of country $L$, the quality, $q$, of manufacturing in country $L$ or the scale, $y$, of the assembler, there is an increase in the proportion $\psi^{M}$ of varieties that are exported by multinational firms of type $M$ and a reduction in the proportion, $\psi^{L}$, of varieties that are exported by contractual suppliers of type L. Overall, a greater variety of parts is produced through international contractual outsourcing at the expense of generic exports.

Proof: For the case $\mathrm{I}^{\mathrm{MH}} \leq \underline{\mathrm{H}}$, the results follow from $\psi^{\mathrm{M}} \equiv 1-\rho(\underline{\mathrm{M}}) / \rho(\underline{\mathrm{H}})=1-(\underline{\mathrm{k}}+\mathrm{F})^{1 / 2} / \mathrm{q}(\underline{\mathrm{k}}+\mathrm{y} \delta / 2)^{1 / 2}$ and $\psi^{\mathrm{L}} \equiv(\rho(\underline{\mathrm{M}})-\rho(\underline{\mathrm{L}})) / \rho(\underline{\mathrm{H}})=(\underline{\mathrm{k}}+\mathrm{F})^{1 / 2} / \mathrm{q}(\underline{\mathrm{k}}+\mathrm{y} \delta / 2)^{1 / 2}$. Similarly for $\underline{\mathrm{H}}<\mathrm{I}^{\mathrm{MH}}$ the results follow from using $\psi^{\mathrm{M}} \equiv 1-\rho(\underline{\mathrm{M}}) / \rho\left(\mathrm{I}^{\mathrm{MH}}\right)$ and $\psi^{\mathrm{L}} \equiv(\rho(\underline{\mathrm{M}})-\rho(\underline{\mathrm{L}})) / \rho\left(\mathrm{I}^{\mathrm{MH}}\right)$.

Thus, by considering the proportion of varieties exported by multinationals or unaffiliated contractual suppliers this Corollary shows that we obtain the following hypothesis:

(III') Increases in the cost-advantage of the low-wage country or the quality of its workforce (with any induced increase in assembler scale) will raise the proportion $\psi^{\mathrm{M}}$ of varieties that are exported by multinational firms, lower the proportion $\psi^{\mathrm{L}}$ of varieties that are exported by contractual suppliers in the low-wage country, and also lower the range of generic exports.

The implications for the range of generic exports from the low-wage country are very similar to what we found without multinationals, so in our testing we will not repeat the regressions related to Chinese ordinary exports (as shown in the upper-half of Tables 1 and 2). Rather, we will focus on processing exports and the range of varieties exported by multinationals versus Chinese-owned firms. 


\section{Estimation}

To test the model predictions for FDI, we re-calculate the extensive margins separately for the processing exports of foreign-owned firms and the processing exports of domestic Chinese firms. Estimates of a gravity equation using the extensive margin as the dependent variable are shown in Table 3 (unweighted) and Table 4 (weighted). (The gravity equations using the intensive margin as the dependent variable are shown in Appendix Table A2, and the predicted intensive margins are used as weights.) The regressions in the top half of Tables 3 and 4 use the extensive margin constructed from the processing exports of domestic firms as the dependent variable, while the regression in the bottom half use the extensive margin constructed from processing exports of foreign-owned firms as the dependent variable. As before, we report the regression at 3-year intervals, using the same regressors as in Tables 1 and 2.

Once again, our primary interest is in the effect of distance on the external margins. In Table 3 , the impact of external distance is insignificant in most cases,${ }^{21}$ while the effect of internal distance is negative and significant in most cases. Furthermore, the impact of internal distance is stronger for the foreign-owned enterprises than for the domestic enterprises, especially in years before 2000. This asymmetry also appears in the weighted regressions of Table 4, where external distance has an insignificant impact on the range of processed goods in all cases, and internal distance has a larger negative impact on the range of processed exports from foreign-owned firms than from domestic firms. These results support the hypothesis (III') that the variety of components produced through offshore production by FDI subsidiaries is more sensitive to transport costs than is the variety of

21 Note that in the cases where the external distance coefficient is significant in Table 3, then it is positive rather than negative. This occurs in several years for the processing exports of foreign-owned firms. It suggested that more distant countries (e.g. the U.S.), will purchase more varieties from foreignowned firms (such as their own subsidiaries). However, this effect is no longer significant in the weighted regressions shown in Table 4. 
contractual exports from domestic Chinese firms. Thus, as one moves towards inland provinces, the distribution of foreign-owned firms engaged in processing becomes sparse more rapidly than domestic firms engaged in processing.

Our second hypothesis is that a higher quality workforce in the source province will contribute to a greater range of processing exports by foreign-owned firms. Recall that we have using the education level of the population as instruments for the manufacturing wage, and so we treat that variable as a measure of workforce quality. In both Tables 3 and 4, the manufacturing wage has a positive impact on the range of processing exports from foreign-owned firms, whereas its coefficient for domestic firms varies in sign and significance across the years. Even when workforce quality (measured by the manufacturing wage) has a positive impact on processing exports of domestic firms, it nearly always has a greater positive impact on the processing exports of foreign-owned firms (with the only exception being 1994 in Table 3). Therefore, an improvement in worker quality increases the proportion of processing varieties being exported by multinationals relative to domestically-owned firms, as in hypothesis (III'). In summary, we have shown that by separating processing exports into varieties exported by multinationals versus those exported by Chinese-owned firms, the multinationals are more sensitive to (internal) distance and workforce quality, as our model implies.

\section{Conclusions}

This paper examines the determinants of the organizational form and location of suppliers at home or abroad in outsourcing relationships. The buyer requires a continuum of parts which vary based on the effectiveness of relationship-specific investment in creating rent for the buyer. Assuming this effectiveness is increasing in the technological sophistication of parts, we obtain the 
following ranking. The range or variety of parts with the highest technological sophistication are produced in the high wage country; as technological sophistication falls, parts are produced in turn, by contractual outsourcing to multinationals in the low-wage country, contractual outsourcing to purely domestic firms in the low-wage country and the purchase of generic parts through the import on non-specialized parts from the low-wage country.

Due to the buyer's outside option of importing generic parts, an important implication of the model is that countries that are closer in physical distance to a low-wage country should benefit from lower trade costs leading to an increase in the variety or range of parts that are imported through contractual rather than generic outsourcing. The model also predicts that as physical distance falls, a greater proportion of imports should be mediated through multinationals rather than direct contractual outsourcing to the low-wage country or through the import of generic parts.

We use a gravity specification based on Chinese export data by province to a large number of destination countries to test these and other predictions. Assuming that contractual exports are represented by processing exports and ordinary manufactures by "generics", the data identifies three organizational forms: foreign owned enterprises (multinational firms), Chinese contractual exporters, and exporters of generic products. Since we are interested in effects on the variety of exports associated with each organizational form, the relevant dependent variable is the "extensive margin" of exports rather than the value of exports traditionally used in gravity equation estimations.

We examine the effects of distance in two dimensions: the "internal" distance from each province to the closest port and then the subsequent "external" distance to the destination country. Although external distance tends to have no significant impact on the extensive margin of either ordinary or processing exports, in most cases internal distance is significant in ways that support our model. First, internal distance has a substantially greater negative impact on processing exports than 
ordinary exports. Indeed, the reduction in the variety of processing exports can be as much as 10 times the reduction in the variety of ordinary exports. Second, within the processing category, there is a significant decrease in the variety of exports supplied by foreign-owned firms as one moves inland, whereas the effect on the variety of exports supplied by Chinese firms tends to be less significant and in many cases, not significant. In sum, these results demonstrate a substantial role for proximity (especially internal distance in China) in shaping the organizational form of outsourcing.

\section{APPENDIX A - Proofs of Propositions}

Proof of Proposition 1: From (6) and (7), we first derive some basic relationships:

$$
\begin{aligned}
& \rho(\underline{\mathrm{L}}) \geq \rho(\underline{\mathrm{H}}) \text { iff } \underline{\mathrm{k}} / \mathrm{y} \delta \geq \beta^{\lambda \mathrm{q} / 2} ; \\
& \rho(\underline{\mathrm{H}}) \geq \rho\left(\mathrm{I}^{\mathrm{LH}}\right) \text { iff } \underline{\mathrm{k}} / \mathrm{y} \delta \geq\left(\beta^{\lambda \mathrm{q}}-1\right) / 4 \\
& \rho(\underline{\mathrm{L}}) \leq \rho\left(\mathrm{I}^{\mathrm{LH}}\right) \text { iff } \underline{\mathrm{k}} / \mathrm{y} \delta \leq \beta^{\lambda q} / 4 .
\end{aligned}
$$

(A) If $\beta^{\lambda q} / 2 \leq \underline{\mathrm{k}} / \mathrm{y} \delta<y / 16 \delta-1 / 2$ then from (A1) and (8), we obtain $\underline{\mathrm{H}} \leq \underline{\mathrm{L}}$ and $\mathrm{I}^{\mathrm{LH}}<\underline{\mathrm{H}}<\check{\mathrm{Z}}$. Thus the assembler prefers $\mathrm{i}=\mathrm{H}$ over $\mathrm{i}=\mathrm{L}$ for the range of $\mathrm{z}$ under which suppliers of type $\mathrm{L}$ would potentially enter and suppliers of type $\mathrm{H}$ are willing to produce whenever suppliers of type $\mathrm{L}$ would enter. Consequently, no contracts $\mathrm{i}=\mathrm{L}$ are awarded. Suppliers of type $\mathrm{i}=\mathrm{H}$ undertake RSI and accept contracts for $\mathrm{z} \in[\underline{\mathrm{H}}, \breve{\mathrm{Z}}]$ and generic parts are imported for $\mathrm{z} \in[0, \underline{\mathrm{H}})$.

(B)(i) If $\left(\beta^{\lambda \mathrm{q}}-1\right) / 4<\underline{\mathrm{k}} / \mathrm{y} \delta<\beta^{\lambda \mathrm{q}} / 2$, then $\underline{\mathrm{L}}<\underline{\mathrm{H}}$ and $\mathrm{I}^{\mathrm{LH}}<\underline{\mathrm{H}}<\check{\mathrm{Z}}$ from (A1) and (8). For both of the possible orderings: $\mathrm{I}^{\mathrm{LH}}<\underline{\mathrm{L}}<\underline{\mathrm{H}}$ and $\underline{\mathrm{L}}<\mathrm{I}^{\mathrm{LH}} \leq \underline{\mathrm{H}}$, the assembler prefers $\mathrm{i}=\mathrm{H}$ relative to $\mathrm{i}=\mathrm{L}$. Thus type $H$ suppliers produce parts $\mathrm{z} \in[\underline{\mathrm{H}}, \breve{Z}$ ) and type $\mathrm{L}$ produce parts $\mathrm{z} \in[\underline{\mathrm{L}}, \underline{\mathrm{H}}$ ) that suppliers of type $\mathrm{H}$ are not willing to produce. Generic parts are imported for $\mathrm{z} \in\left[0, \underline{\mathrm{L}}\right.$ ). (B)(ii) If $\underline{\mathrm{k}} / \mathrm{y} \delta<\left(\beta^{\lambda q}-1\right) / 4$, 
then $\underline{\mathrm{L}}<\underline{\mathrm{H}}<\mathrm{I}^{\mathrm{LH}}$ from (A1) and $\mathrm{I}^{\mathrm{LH}}<\breve{\mathrm{Z}}$ from (8). We have $\beta^{\lambda \mathrm{q}}>1$ due to $\underline{\mathrm{k}} / \mathrm{y} \delta>0$. The assembler chooses type $\mathrm{H}$ for $\mathrm{z} \in\left[\mathrm{I}^{\mathrm{LH}}, \breve{\mathrm{Z}}\right]$ and type $\mathrm{L}$ for $\mathrm{z} \in\left[\underline{\mathrm{L}}, \mathrm{I}^{\mathrm{LH}}\right)$. Generic parts are imported for $\mathrm{z} \in[0, \underline{\mathrm{L}})$.

Proof of Proposition 2: From (7), (14) and (15), we obtain

$$
\begin{aligned}
& \rho(\underline{\mathrm{M}}) \geq \rho\left(\mathrm{I}^{\mathrm{MH}}\right) \text { iff }(\underline{\mathrm{k}}+\mathrm{F}) / \mathrm{y} \delta \geq \beta^{\mathrm{q}} / 4 . \\
& \rho(\underline{\mathrm{M}}) \geq \rho(\underline{\mathrm{H}}) \text { iff } \mathrm{F} / \mathrm{y} \delta \geq\left[\beta^{\mathrm{q}} / 2-\underline{\mathrm{k}} / \mathrm{y} \delta\right] /\left(1+\beta^{\mathrm{q}}\right) \\
& \rho(\underline{\mathrm{H}}) \geq \rho\left(\mathrm{I}^{\mathrm{MH}}\right) \text { iff } \underline{\mathrm{k}} / \mathrm{y} \delta \geq\left(\beta^{\mathrm{q}}-1\right) / 4 \\
& \rho(\underline{\mathrm{L}})<\rho(\underline{\mathrm{M}}) \text { iff } \mathrm{F}>\underline{\mathrm{k}}\left(1-(\lambda)^{2}\right) /(\lambda)^{2}=\underline{\mathrm{k}} / \beta^{\lambda} .
\end{aligned}
$$

A further useful relationship is

$$
\underline{\mathrm{k}} / \mathrm{y} \delta \geq\left(\beta^{\mathrm{q}}-1\right) / 4 \operatorname{iff}\left(\beta^{\mathrm{q}} / 2-\underline{\mathrm{k}} / \mathrm{y} \delta\right) /\left(1+\beta^{\mathrm{q}}\right) \leq 1 / 4 .
$$

(A) Since $\left(\beta^{\mathrm{q}} / 2-\underline{\mathrm{k}} / \mathrm{y} \delta\right) /\left(1+\beta^{\mathrm{q}}\right) \leq \mathrm{F} / \mathrm{y} \delta<1 / 4$, we obtain $\underline{\mathrm{k}} / \mathrm{y} \delta \geq\left(\beta^{\mathrm{q}}-1\right) / 4$ from (A3) and it follows from (A2) that $\mathrm{I}^{\mathrm{MH}} \leq \underline{\mathrm{H}} \leq \underline{\mathrm{M}}$. The assembler chooses $\mathrm{H}$ for $\mathrm{z} \in[\underline{\mathrm{H}}, \check{\mathrm{Z}}]$ and there is no FDI. Proposition 1, parts (A) and (B)(i) then apply, but since $\beta^{\lambda \mathrm{q}}<\beta^{\mathrm{q}}$ and $\underline{\mathrm{k}} / \mathrm{y} \delta \geq\left(\beta^{\mathrm{q}}-1\right) / 4$, we have $\underline{\mathrm{k}} / \mathrm{y} \delta$ $>\left(\beta^{\lambda q}-1\right) / 4$ ruling out part $B($ ii).

(B)(i)(a) From F/y $\delta<\left(\beta^{q} / 2-\underline{\mathrm{k}} / \mathrm{y} \delta\right) /\left(1+\beta^{\mathrm{q}}\right), \underline{\mathrm{k}} / \mathrm{y} \delta \geq\left(\beta^{\mathrm{q}}-1\right) / 4$ and (A2), we obtain $\underline{\mathrm{M}}<\underline{\mathrm{H}}$ and $\mathrm{I}^{\mathrm{MH}}$ $<\underline{\mathrm{H}}$.

(b) From $\mathrm{F} / \mathrm{y} \delta<\left(\beta^{\mathrm{q}} / 2-\underline{\mathrm{k}} / \mathrm{y} \delta\right) /\left(1+\beta^{\mathrm{q}}\right), \underline{\mathrm{k}} / \mathrm{y} \delta<\left(\beta^{\mathrm{q}}-1\right) / 4$ and (A2), we obtain $\underline{\mathrm{M}}<\underline{\mathrm{H}}<\mathrm{I}^{\mathrm{MH}}$.

(B)(ii) From (A2), $\underline{\mathrm{L}}<\underline{\mathrm{M}}$ iff $\mathrm{F}>\underline{\mathrm{k}}\left(1-(\lambda)^{2}\right) /(\lambda)^{2}=\underline{\mathrm{k}} / \beta^{\lambda}$. Since $\mathrm{r}^{\mathrm{L}}=(\lambda)^{2} \mathrm{r}^{\mathrm{M}}$ where $\lambda<1$, the assembler prefers $\mathrm{M}$ over $\mathrm{L}$ and chooses $\mathrm{L}$ only for parts $\mathrm{z} \in[\underline{\mathrm{L}}, \underline{\mathrm{M}})$. 


\section{APPENDIX B - Data Sources}

Chinese export data are from the Customs General Administration of the People's Republic of China (China. Customs General Administration, Statistics Department. "China Trade Information." Hong Kong: Economic Information Agency). These data are purchased from Mr. George Chen, China Customs Statistics Information Center, Economic Information Agency, Hong Kong, EIAET@PACIFIC.NET.HK, and are used to construct the extensive margins used as the dependent variables in Tables 1 - 4. The independent variables are obtained from various sources:

1) China's Regional Economy After Seventeen Years Reform and Open, Xinjiang Statistical Bureau, 1998, which is a collection of data from the provincial statistic yearbooks for 1978-1995.

2) China's Statistic Yearbook, 1989-2004: used for provincial GDP, population and wages.

3) Chinese railroad timetable: used for the Internal distance: measured by train hours.

The external distance is taken from Lin (2001) and Ma (2004), and is the external shipping distance between Chinese ports and the international ports, which is obtained from a special world map designed for sketching ocean transportation.

4) Major figures of the Fourth National Population Census of China, 1991, China Statistics Publisher House: used for the percentages of the population with primary, junior, senior and university education.

5) GDP and population of the destination markets are taken from the Penn World Tables. 
Appendix Table C1: Intensive Margin, Manufacturing Exports

\begin{tabular}{|c|c|c|c|c|c|}
\hline \multicolumn{6}{|c|}{ Ordinary Export } \\
\hline & 1988 & 1991 & 1994 & 1997 & 2000 \\
\hline GDP per capita & $0.97^{\star \star}$ & $1.18^{\star \star}$ & $1.17^{\star \star}$ & $1.02^{\star \star}$ & $0.89^{\star \star}$ \\
\hline (province) & $(0.24)$ & $(0.17)$ & $(0.16)$ & $(0.17)$ & $(0.17)$ \\
\hline \multirow[t]{2}{*}{ Manufact wage } & $4.12^{\star \star}$ & 1.53 & $2.33^{\star \star}$ & $1.38^{\star \star}$ & $0.75^{\star}$ \\
\hline & (1.63) & $(0.89)$ & $(0.35)$ & $(0.27)$ & $(0.29)$ \\
\hline \multirow{2}{*}{$\begin{array}{l}\text { GDP per capita } \\
\text { (country) }\end{array}$} & $0.12^{\star \star}$ & $0.21^{\star *}$ & $0.22^{\star \star}$ & $0.20 * \star$ & $0.23^{\star *}$ \\
\hline & $(0.02)$ & $(0.01)$ & $(0.01)$ & $(0.01)$ & $(0.01)$ \\
\hline \multirow{2}{*}{$\begin{array}{l}\text { Population } \\
\quad \text { (province) }\end{array}$} & $0.65^{\star \star}$ & $0.77^{\star \star}$ & $0.83^{\star \star}$ & $0.78^{\star \star}$ & $0.85^{\star \star}$ \\
\hline & $(0.09)$ & $(0.07)$ & $(0.05)$ & $(0.04)$ & $(0.05)$ \\
\hline \multirow{2}{*}{$\begin{array}{l}\text { Population } \\
\text { (country) }\end{array}$} & $0.58^{\star \star}$ & $0.62^{\star \star}$ & $0.70^{\star \star}$ & $0.90 * \star$ & $0.88^{\star *}$ \\
\hline & $(0.03)$ & $(0.03)$ & $(0.02)$ & $(0.02)$ & $(0.02)$ \\
\hline \multirow[t]{2}{*}{ External distance } & $-1.46^{\star *}$ & $-1.44^{* *}$ & $-1.13^{\star \star}$ & $-0.96^{\star \star}$ & $-0.87^{\star *}$ \\
\hline & $(0.09)$ & $(0.06)$ & $(0.05)$ & $(0.05)$ & $(0.05)$ \\
\hline \multirow[t]{2}{*}{ Internal distance } & -0.08 & $-0.08^{*}$ & -0.06 & $-0.19 \star \star$ & $-0.33^{\star \star}$ \\
\hline & $(0.05)$ & $(0.04)$ & $(0.04)$ & $(0.03)$ & $(0.04)$ \\
\hline \multirow{2}{*}{$\begin{array}{l}\text { Observations } \\
\text { R-squared }\end{array}$} & 1912 & 2219 & 2850 & 2861 & 2843 \\
\hline & 0.34 & 0.45 & 0.5 & 0.56 & 0.54 \\
\hline \multirow{2}{*}{ R-squared } & \multicolumn{4}{|c|}{ Processing Export } & \\
\hline & 1988 & 1991 & 1994 & 1997 & 2000 \\
\hline \multirow{2}{*}{$\begin{array}{l}\text { GDP per capita } \\
\text { (province) }\end{array}$} & 0.05 & $0.54^{\star \star}$ & 0.31 & 0.32 & 0.37 \\
\hline & $(0.25)$ & $(0.21)$ & $(0.20)$ & $(0.21)$ & $(0.21)$ \\
\hline \multirow[t]{2}{*}{ Manufact wage } & $6.27^{\star \star}$ & $3.98^{\star \star}$ & $2.09^{\star \star}$ & $1.28^{\star \star}$ & $0.83^{\star}$ \\
\hline & $(1.70)$ & $(1.04)$ & $(0.48)$ & $(0.34)$ & $(0.37)$ \\
\hline $\begin{array}{l}\text { GDP per capita } \\
\text { (country) }\end{array}$ & $\begin{array}{l}0.09 * * \\
(0.01)\end{array}$ & $\begin{array}{l}0.18^{\star \star} \\
(0.02)\end{array}$ & $\begin{array}{l}0.20^{\star \star} \\
(0.01)\end{array}$ & $\begin{array}{l}0.21 * \star \\
(0.01)\end{array}$ & $\begin{array}{l}0.23^{\star \star} \\
(0.01)\end{array}$ \\
\hline \multirow{2}{*}{$\begin{array}{l}\text { Population } \\
\text { (province) }\end{array}$} & $0.41 * \star$ & 0.50 ** & $0.39 \star \star$ & $0.48^{\star \star}$ & 0.50 ** \\
\hline & $(0.08)$ & $(0.08)$ & $(0.07)$ & $(0.06)$ & $(0.07)$ \\
\hline \multirow{2}{*}{$\begin{array}{l}\text { Population } \\
\text { (country) }\end{array}$} & $0.46^{\star \star}$ & $0.52^{\star *}$ & $0.61^{\star *}$ & $0.77^{\star \star}$ & $0.73^{\star \star}$ \\
\hline & $(0.04)$ & $(0.03)$ & $(0.03)$ & $(0.03)$ & $(0.03)$ \\
\hline \multirow[t]{2}{*}{ External distance } & $-1.19 * *$ & $-1.22^{\star *}$ & $-1.18^{\star \star}$ & $-1.16^{\star \star}$ & $-1.01^{\star \star}$ \\
\hline & $(0.09)$ & $(0.07)$ & $(0.07)$ & $(0.07)$ & $(0.09)$ \\
\hline \multirow[t]{2}{*}{ Internal distance } & $-0.26^{\star \star}$ & $-0.15^{\star \star}$ & $-0.16^{\star \star}$ & $-0.28^{\star \star}$ & $-0.28^{* *}$ \\
\hline & $(0.05)$ & $(0.05)$ & $(0.06)$ & $(0.05)$ & $(0.05)$ \\
\hline \multirow{2}{*}{$\begin{array}{l}\text { Observations } \\
\text { R-squared }\end{array}$} & 1757 & 2015 & 2399 & 2382 & 2310 \\
\hline & 0.31 & 0.36 & 0.39 & 0.43 & 0.39 \\
\hline
\end{tabular}


Appendix Table C2: Intensive Margin, Processing Exports

\begin{tabular}{|c|c|c|c|c|c|}
\hline \multicolumn{6}{|c|}{ Domestic Firms } \\
\hline & 1988 & 1991 & 1994 & 1997 & 2000 \\
\hline GDP per capita & -0.37 & $0.58^{\star}$ & $1.13^{\star \star}$ & 0.49 & 0.19 \\
\hline (province) & $(0.34)$ & $(0.26)$ & $(0.22)$ & $(0.26)$ & $(0.23)$ \\
\hline \multirow[t]{2}{*}{ Manufact wage } & $6.99 * \star$ & $2.37^{\star}$ & $1.77^{\star \star}$ & $1.41^{\star \star}$ & $1.57^{\star \star}$ \\
\hline & $(1.62)$ & $(1.05)$ & $(0.58)$ & $(0.44)$ & $(0.43)$ \\
\hline \multirow{2}{*}{$\begin{array}{l}\text { GDP per capita } \\
\text { (country) }\end{array}$} & $0.12^{\star \star}$ & $0.15^{\star \star}$ & $0.22^{\star \star}$ & $0.18^{\star \star}$ & $0.18^{\star \star}$ \\
\hline & $(0.02)$ & $(0.02)$ & $(0.01)$ & $(0.01)$ & $(0.01)$ \\
\hline \multirow{2}{*}{$\begin{array}{l}\text { Population } \\
\text { (province) }\end{array}$} & -0.002 & $0.39 * \star$ & $0.56^{\star \star}$ & $0.57^{\star \star}$ & $0.59 \star \star$ \\
\hline & $(0.12)$ & $(0.09)$ & $(0.07)$ & $(0.07)$ & $(0.08)$ \\
\hline \multirow{2}{*}{$\begin{array}{l}\text { Population } \\
\text { (country) }\end{array}$} & $0.47^{\star \star}$ & $0.50^{\star \star}$ & $0.62^{\star \star}$ & $0.72^{\star \star}$ & $0.64^{\star \star}$ \\
\hline & $(0.04)$ & $(0.04)$ & $(0.03)$ & $(0.04)$ & $(0.03)$ \\
\hline \multirow[t]{2}{*}{ External distance } & $-1.22^{\star \star}$ & $-1.19^{\star \star}$ & $-1.16^{\star \star}$ & $-1.13^{\star *}$ & $-1.16^{\star \star}$ \\
\hline & $(0.10)$ & $(0.07)$ & $(0.07)$ & $(0.07)$ & $(0.08)$ \\
\hline \multirow[t]{2}{*}{ Internal distance } & $-0.16^{\star \star}$ & $-0.20^{\star \star}$ & -0.02 & -0.06 & -0.04 \\
\hline & $(0.06)$ & $(0.05)$ & $(0.06)$ & $(0.05)$ & $(0.05)$ \\
\hline & 1272 & 1513 & 1689 & 1648 & 1754 \\
\hline & 0.32 & 0.34 & 0.42 & 0.38 & 0.37 \\
\hline \multirow{2}{*}{ R-squared } & \multicolumn{4}{|c|}{ Foreign Owned Firms } & \\
\hline & 1988 & 1991 & 1994 & 1997 & 2000 \\
\hline \multirow{2}{*}{$\begin{array}{l}\text { GDP per capita } \\
\text { (province) }\end{array}$} & $-1.11^{\star *}$ & -0.24 & -0.51 & 0.12 & 0.08 \\
\hline & $(0.44)$ & $(0.32)$ & $(0.31)$ & $(0.35)$ & $(0.36)$ \\
\hline \multirow[t]{2}{*}{ Manufact wage } & $4.07^{*}$ & 1.6 & -0.15 & 0.14 & 0.33 \\
\hline & $(1.89)$ & $(1.21)$ & $(0.77)$ & $(0.56)$ & $(0.61)$ \\
\hline \multirow{2}{*}{$\begin{array}{l}\text { GDP per capita } \\
\text { (country) }\end{array}$} & $0.16^{\star \star}$ & $0.26^{\star \star}$ & $0.28^{\star \star}$ & $0.25^{\star \star}$ & $0.23^{\star \star}$ \\
\hline & $(0.02)$ & $(0.02)$ & $(0.02)$ & $(0.02)$ & $(0.02)$ \\
\hline \multirow{2}{*}{$\begin{array}{l}\text { Population } \\
\text { (province) }\end{array}$} & $-0.51^{\star \star}$ & 0.15 & 0.17 & $0.26^{\star \star}$ & 0.11 \\
\hline & $(0.17)$ & $(0.10)$ & $(0.10)$ & $(0.09)$ & $(0.09)$ \\
\hline \multirow{2}{*}{$\begin{array}{l}\text { Population } \\
\text { (country) }\end{array}$} & $0.42^{\star \star}$ & $0.54^{\star \star}$ & $0.62^{\star \star}$ & $0.71^{\star \star}$ & $0.63^{\star \star}$ \\
\hline & $(0.05)$ & $(0.04)$ & $(0.04)$ & $(0.04)$ & $(0.04)$ \\
\hline \multirow[t]{2}{*}{ External distance } & $-1.35^{\star \star}$ & $-1.18^{\star \star}$ & $-1.10^{\star \star}$ & $-1.03^{\star \star}$ & $-1.03^{\star *}$ \\
\hline & $(0.11)$ & $(0.09)$ & $(0.08)$ & $(0.09)$ & $(0.11)$ \\
\hline \multirow[t]{2}{*}{ Internal distance } & $-0.16^{\star}$ & $-0.31^{\star \star}$ & $-0.55^{\star \star}$ & $-0.37^{\star \star}$ & $-0.34^{\star *}$ \\
\hline & $(0.07)$ & $(0.06)$ & $(0.07)$ & $(0.06)$ & $(0.06)$ \\
\hline Observations & 1104 & 1269 & 1462 & 1493 & 1518 \\
\hline R-squared & 0.27 & 0.33 & 0.33 & 0.33 & 0.3 \\
\hline
\end{tabular}

Robust standard errors are in parentheses, * significant at 5\%; ** significant at $1 \%$ A constant term is included in the regression (but not reported). Instruments used for GDP per capita (province) and the manufacturing wage are the percentage of population with primary, junior, senior and university education. 


\section{References}

Acemoglu, Daron, Philippe Aghion, Rachel Griffith and Fabrizio Zillibotti, 2004. "Vertical Integration and Technology: Theory and Evidence”, NBER working paper w10997

Aghion, Phillipe and Jean Tirole, 1997. “Formal and Real Authority in Organizations,” Journal of Political Economy, 105(1), 1-29.

Antràs, Pol, 2003. “Firms, Contracts, and Trade Structure,” Quarterly Journal of Economics 118, $1375-1418$

Antràs, Pol, 2005. "Incomplete Contracts and the Product Cycle,” American Economic Review, 95(4), September, 1054-1073

Antràs, Pol and Elhanan Helpman, 2004. “Global Sourcing,” Journal of Political Economy 112 (3), 552-580.

Chen, Yongmin and Robert C. Feenstra, 2005. "Buyer Investment, Product Variety, and Intrafirm Trade,” NBER Working paper No. 11752.

Evans, Carolyn and James Harrigan, 2005. "Distance, Time and Specialization,” American Economic Review, 95(1), March, 292-313.

Feenstra, Robert C., 1994. "New Product Varieties and the Measurement of International Prices," American Economic Review, 84(1), March, 157-177.

Feenstra, Robert C. and Gordon H. Hanson, 2005. "Ownership and Control in Outsourcing to China,” Quarterly Journal of Economics, 120 (2), 729-761.

Grossman, Gene M. and Elhanan Helpman, 2002. "Integration versus Outsourcing in Industry Equilibrium,” Quarterly Journal of Economics 117(1), 85-120

Grossman, Gene M. and Elhanan Helpman, 2004. "Managerial Incentives and International Organization of Production,” Journal of International Economics 63, 237-262

Grossman, Gene M. and Elhanan Helpman, 2005. “Outsourcing in a Global Economy,” Review of Economic Studies, 72 (1), 135-160

Grossman, Sanford J and Oliver D. Hart, 1986. "Costs and Benefits of Ownership: A Theory of Vertical and Lateral Integration,” Journal of Political Economy, 94(4), August, 691 - 719.

Head Keith, Ries John and Barbara J. Spencer, 2004. "Vertical Networks and U.S. Auto Parts Exports: Is Japan Different?”, Journal of Economics and Management Strategy, 13(1), 37- 67. 
Helpman, Elhanan, 2005. “Trade, FDI, and the Organization of Firms,” Harvard University and CIAR.

Hillberry, Russell and David L. Hummels, 2005. “Trade Responses to Geographic Frictions: A Decomposition Using Micro-Data,” University of Melbourne and Purdue University.

Holmstrom, Bengt and Paul Milgrom, 1994. "The Firm as an Incentive System," American Economic Review, 84(4), 972-991.

Hummels, David L. and Klenow, Peter J., 2005. “The Variety and Quality of a Nation's Trade,” American Economic Review, 95(3), June 704-723.

Lin, Songhua, 2000. “International Trade, Location and Wage Inequality in China,” University of California, Davis, Ph.D. dissertation.

Ma, Alyson, 2004. “Geographical Location of Foreign Direct Investment and Wage Inequality in China,” University of California, Davis, Ph.D. dissertation.

Marin, Dalia and Thierry Verdier, 2002. "Power Inside the Firm and the Market: A General Equilibrium Approach,” Centre for Economic Policy Research Discussion Paper No. 4358, London

Marin, Dalia and Thierry Verdier, 2003. “Globalization and the Empowerment of Talent,” Centre for Economic Policy Research Discussion Paper No. 4129, December

Puga, Diego and Daniel Trefler. 2002. “Knowledge Creation and Control in Organizations.” NBER Working Paper no. 9121.

Qiu, Larry D. and Barbara J. Spencer, 2002. "Keiretsu and Relationship-Specific Investments: Implications for Market-Opening Policy,” Journal of International Economics, 58(1), 49-79.

Spencer, Barbara J and Larry Qiu, 2001. "Keiretsu and Relationship-Specific Investments: A Barrier to Trade?”, International Economic Review, 42 (4), 871-901.

Spencer, Barbara J., 2005. “International Outsourcing and Incomplete Contracts,” Canadian Journal of Economics, 38(4), November, 1107-1135.

Schwartz, Galina A. and Ari Van Assche, 2005. "Firm Heterogeneity, Input Specificity and the Optimal Outsourcing Strategy,” HEC Montreal and UC Berkeley. 
Table 1: Extensive Margin, Manufacturing Exports (Unweighted)

\begin{tabular}{|c|c|c|c|c|c|}
\hline \multicolumn{6}{|c|}{ Ordinary Export } \\
\hline & 1988 & 1991 & 1994 & 1997 & 2000 \\
\hline $\begin{array}{l}\text { GDP per capita } \\
\text { (province) }\end{array}$ & $\begin{array}{l}0.360^{\star \star} \\
(0.011)\end{array}$ & $\begin{array}{l}0.248^{\star *} \\
(0.008)\end{array}$ & $\begin{array}{l}0.148^{\star \star} \\
(0.006)\end{array}$ & $\begin{array}{l}0.170^{\star *} \\
(0.007)\end{array}$ & $\begin{array}{l}0.135^{\star \star} \\
(0.005)\end{array}$ \\
\hline Manufact wage & $\begin{array}{c}-0.613^{\star *} \\
(0.070)\end{array}$ & $\begin{array}{c}-0.506^{\star \star} \\
(0.034)\end{array}$ & $\begin{array}{c}-0.033^{\star *} \\
(0.010)\end{array}$ & $\begin{array}{c}-0.126^{\star \star} \\
(0.009)\end{array}$ & $\begin{array}{l}-0.058^{* \star} \\
(0.006)\end{array}$ \\
\hline $\begin{array}{l}\text { GDP per capita } \\
\text { (country) }\end{array}$ & $\begin{array}{l}-0.001 \\
(0.001)\end{array}$ & $\begin{array}{c}0.000 \\
(0.001)\end{array}$ & $\begin{array}{l}-0.000 \\
(0.000)\end{array}$ & $\begin{array}{l}-0.000 \\
(0.000)\end{array}$ & $\begin{array}{l}-0.001 \\
(0.000)\end{array}$ \\
\hline $\begin{array}{l}\text { Population } \\
\text { (province) }\end{array}$ & $\begin{array}{l}0.231^{\star *} \\
(0.007)\end{array}$ & $\begin{array}{l}0.143^{* *} \\
(0.005)\end{array}$ & $\begin{array}{l}0.072^{\star *} \\
(0.002)\end{array}$ & $\begin{array}{l}0.057^{\star \star} \\
(0.002)\end{array}$ & $\begin{array}{l}0.072^{\star *} \\
(0.003)\end{array}$ \\
\hline $\begin{array}{l}\text { Population } \\
\text { (country) }\end{array}$ & $\begin{array}{l}-0.002 \\
(0.002)\end{array}$ & $\begin{array}{c}0.000 \\
(0.001)\end{array}$ & $\begin{array}{l}-0.001 \\
(0.001)\end{array}$ & $\begin{array}{l}-0.001 \\
(0.001)\end{array}$ & $\begin{array}{l}-0.001 \\
(0.001)\end{array}$ \\
\hline External distance & $\begin{array}{l}-0.000 \\
(0.003)\end{array}$ & $\begin{array}{c}0.000 \\
(0.002)\end{array}$ & $\begin{array}{c}0.001 \\
(0.001)\end{array}$ & $\begin{array}{l}-0.001 \\
(0.002)\end{array}$ & $\begin{array}{c}0.000 \\
(0.002)\end{array}$ \\
\hline Internal distance & $\begin{array}{c}-0.050 \star * \\
(0.003)\end{array}$ & $\begin{array}{l}-0.049 * * \\
(0.002)\end{array}$ & $\begin{array}{l}-0.001 \\
(0.002)\end{array}$ & $\begin{array}{c}-0.007^{\star *} \\
(0.001)\end{array}$ & $\begin{array}{r}-0.010^{\star \star} \\
(0.001)\end{array}$ \\
\hline $\begin{array}{l}\text { Observations } \\
\text { R-squared }\end{array}$ & $\begin{array}{l}1912 \\
0.79 \\
\end{array}$ & $\begin{array}{l}2219 \\
0.77 \\
\end{array}$ & $\begin{array}{l}2850 \\
0.57 \\
\end{array}$ & $\begin{array}{l}2861 \\
0.62 \\
\end{array}$ & $\begin{array}{l}2843 \\
0.59 \\
\end{array}$ \\
\hline \multicolumn{6}{|c|}{ Processing Export } \\
\hline $\begin{array}{l}\text { GDP per capita } \\
\text { (province) }\end{array}$ & $\begin{array}{l}0.495^{\star \star} \\
(0.052)\end{array}$ & $\begin{array}{l}0.549^{\star *} \\
(0.043)\end{array}$ & $\begin{array}{l}0.866^{\star \star} \\
(0.040)\end{array}$ & $\begin{array}{l}0.833^{\star *} \\
(0.045)\end{array}$ & $\begin{array}{l}0.678^{\star \star} \\
(0.042)\end{array}$ \\
\hline Manufact wage & $\begin{array}{c}0.218 \\
(0.301)\end{array}$ & $\begin{array}{c}0.309 \\
(0.241)\end{array}$ & $\begin{array}{l}-0.087 \\
(0.087)\end{array}$ & $\begin{array}{l}-0.099 \\
(0.083)\end{array}$ & $\begin{array}{l}0.272^{\star *} \\
(0.093)\end{array}$ \\
\hline $\begin{array}{l}\text { GDP per capita } \\
\text { (country) }\end{array}$ & $\begin{array}{c}0.003 \\
(0.002)\end{array}$ & $\begin{array}{c}0.001 \\
(0.003)\end{array}$ & $\begin{array}{c}0.001 \\
(0.002)\end{array}$ & $\begin{array}{l}-0.002 \\
(0.002)\end{array}$ & $\begin{array}{l}-0.008^{\star \star} \\
(0.002)\end{array}$ \\
\hline $\begin{array}{l}\text { Population } \\
\text { (province) }\end{array}$ & $\begin{array}{l}0.429^{\star \star} \\
(0.032)\end{array}$ & $\begin{array}{l}0.451^{\star *} \\
(0.023)\end{array}$ & $\begin{array}{l}0.470^{\star \star} \\
(0.016)\end{array}$ & $\begin{array}{l}0.412^{\star \star} \\
(0.013)\end{array}$ & $\begin{array}{l}0.435^{\star \star} \\
(0.012)\end{array}$ \\
\hline $\begin{array}{l}\text { Population } \\
\text { (country) }\end{array}$ & $\begin{array}{l}-0.003 \\
(0.005)\end{array}$ & $\begin{array}{c}0.003 \\
(0.005)\end{array}$ & $\begin{array}{l}-0.001 \\
(0.005)\end{array}$ & $\begin{array}{c}-0.012^{\star *} \\
(0.005)\end{array}$ & $\begin{array}{c}-0.017^{\star \star} \\
(0.005)\end{array}$ \\
\hline External distance & $\begin{array}{l}-0.015 \\
(0.012)\end{array}$ & $\begin{array}{l}-0.018 \\
(0.012)\end{array}$ & $\begin{array}{l}-0.013 \\
(0.011)\end{array}$ & $\begin{array}{c}0.007 \\
(0.011)\end{array}$ & $\begin{array}{l}0.028^{*} \\
(0.012)\end{array}$ \\
\hline Internal distance & $\begin{array}{c}-0.090^{* *} \\
(0.008) \\
\end{array}$ & $\begin{array}{l}-0.101^{\star *} \\
(0.010)\end{array}$ & $\begin{array}{c}-0.065^{\star \star} \\
(0.009) \\
\end{array}$ & $\begin{array}{c}-0.098^{\star *} \\
(0.007) \\
\end{array}$ & $\begin{array}{c}-0.114^{\star \star} \\
(0.007) \\
\end{array}$ \\
\hline Observations & 1757 & 2015 & 2399 & 2382 & 2310 \\
\hline R-squared & 0.51 & 0.52 & 0.65 & 0.70 & 0.73 \\
\hline
\end{tabular}

Robust standard errors in parentheses * significant at 5\%; ** significant at 1\%

A constant term is included in the regression (but not reported). Instruments used for GDP per capita (province) and the manufacturing wage are the percentages of the population with primary, junior, senior and university education. 
Table 2: Extensive Margin, Manufacturing Exports (Weighted)

\begin{tabular}{|c|c|c|c|c|c|}
\hline \multicolumn{6}{|c|}{ Ordinary Export } \\
\hline & 1988 & 1991 & 1994 & 1997 & 2000 \\
\hline $\begin{array}{l}\text { GDP per capita } \\
\text { (province) }\end{array}$ & $\begin{array}{l}0.293^{\star \star} \\
(0.024)\end{array}$ & $\begin{array}{l}0.195^{\star \star} \\
(0.020)\end{array}$ & $\begin{array}{l}0.066^{\star *} \\
(0.011)\end{array}$ & $\begin{array}{l}0.054^{\star *} \\
(0.015)\end{array}$ & $\begin{array}{l}0.108^{\star *} \\
(0.012)\end{array}$ \\
\hline Manufact wage & $\begin{array}{c}-0.126^{\star \star} \\
(0.048)\end{array}$ & $\begin{array}{c}-0.209^{* *} \\
(0.042)\end{array}$ & $\begin{array}{l}0.100^{* *} \\
(0.033)\end{array}$ & $\begin{array}{l}-0.010 \\
(0.022)\end{array}$ & $\begin{array}{c}-0.066^{\star *} \\
(0.013)\end{array}$ \\
\hline $\begin{array}{l}\text { GDP per capita } \\
\text { (country) }\end{array}$ & $\begin{array}{c}0.000 \\
(0.001)\end{array}$ & $\begin{array}{c}0.001 \\
(0.001)\end{array}$ & $\begin{array}{l}-0.000 \\
(0.001)\end{array}$ & $\begin{array}{c}0.000 \\
(0.001)\end{array}$ & $\begin{array}{c}0.000 \\
(0.001)\end{array}$ \\
\hline $\begin{array}{l}\text { Population } \\
\text { (province) }\end{array}$ & $\begin{array}{l}0.241^{\star *} \\
(0.016)\end{array}$ & $\begin{array}{l}0.157^{\star *} \\
(0.009)\end{array}$ & $\begin{array}{l}0.049^{* *} \\
(0.004)\end{array}$ & $\begin{array}{l}0.039 * * \\
(0.004)\end{array}$ & $\begin{array}{l}0.031^{\star *} \\
(0.003)\end{array}$ \\
\hline $\begin{array}{l}\text { Population } \\
\text { (country) }\end{array}$ & $\begin{array}{c}0.000 \\
(0.002)\end{array}$ & $\begin{array}{l}-0.000 \\
(0.002)\end{array}$ & $\begin{array}{c}0.000 \\
(0.001)\end{array}$ & $\begin{array}{l}-0.000 \\
(0.002)\end{array}$ & $\begin{array}{l}-0.000 \\
(0.001)\end{array}$ \\
\hline External distance & $\begin{array}{l}-0.000 \\
(0.003)\end{array}$ & $\begin{array}{l}-0.005 \\
(0.003)\end{array}$ & $\begin{array}{c}0.001 \\
(0.002)\end{array}$ & $\begin{array}{l}-0.001 \\
(0.002)\end{array}$ & $\begin{array}{l}-0.002 \\
(0.001)\end{array}$ \\
\hline Internal distance & $\begin{array}{l}-0.040^{\star *} \\
(0.005) \\
\end{array}$ & $\begin{array}{c}-0.046^{\star *} \\
(0.004) \\
\end{array}$ & $\begin{array}{c}0.003 \\
(0.003) \\
\end{array}$ & $\begin{array}{c}-0.016^{\star *} \\
(0.002) \\
\end{array}$ & $\begin{array}{l}-0.004 \\
(0.002) \\
\end{array}$ \\
\hline $\begin{array}{l}\text { Observations } \\
\text { R-squared }\end{array}$ & $\begin{array}{l}1912 \\
0.83\end{array}$ & $\begin{array}{l}2219 \\
0.84\end{array}$ & $\begin{array}{l}2850 \\
0.36\end{array}$ & $\begin{array}{l}2861 \\
0.54\end{array}$ & $\begin{array}{l}2843 \\
0.40\end{array}$ \\
\hline \multicolumn{6}{|c|}{ Processing Export } \\
\hline & 1988 & 1991 & 1994 & 1997 & 2000 \\
\hline $\begin{array}{l}\text { GDP per capita } \\
\text { (province) }\end{array}$ & $\begin{array}{l}0.585^{\star \star} \\
(0.120)\end{array}$ & $\begin{array}{l}0.518^{\star \star} \\
(0.056)\end{array}$ & $\begin{array}{l}0.581^{\star *} \\
(0.095)\end{array}$ & $\begin{array}{l}0.593^{\star \star} \\
(0.081)\end{array}$ & $\begin{array}{l}0.618^{\star *} \\
(0.069)\end{array}$ \\
\hline Manufact wage & $\begin{array}{l}-0.098 \\
(0.131)\end{array}$ & $\begin{array}{l}-0.302^{\star} \\
(0.134)\end{array}$ & $\begin{array}{l}0.607^{\star} \\
(0.237)\end{array}$ & $\begin{array}{c}0.127 \\
(0.123)\end{array}$ & $\begin{array}{c}0.178 \\
(0.116)\end{array}$ \\
\hline $\begin{array}{l}\text { GDP per capita } \\
\text { (country) }\end{array}$ & $\begin{array}{c}0.001 \\
(0.002)\end{array}$ & $\begin{array}{l}-0.001 \\
(0.003)\end{array}$ & $\begin{array}{c}0.002 \\
(0.006)\end{array}$ & $\begin{array}{c}0.002 \\
(0.004)\end{array}$ & $\begin{array}{l}-0.006 \\
(0.004)\end{array}$ \\
\hline $\begin{array}{l}\text { Population } \\
\text { (province) }\end{array}$ & $\begin{array}{l}0.408^{\star \star} \\
(0.082)\end{array}$ & $\begin{array}{l}0.304^{\star *} \\
(0.029)\end{array}$ & $\begin{array}{l}0.342^{\star *} \\
(0.031)\end{array}$ & $\begin{array}{l}0.321^{\star *} \\
(0.022)\end{array}$ & $\begin{array}{l}0.351^{\star *} \\
(0.018)\end{array}$ \\
\hline $\begin{array}{l}\text { Population } \\
\text { (country) }\end{array}$ & $\begin{array}{l}-0.004 \\
(0.007)\end{array}$ & $\begin{array}{c}0.001 \\
(0.006)\end{array}$ & $\begin{array}{c}0.002 \\
(0.010)\end{array}$ & $\begin{array}{l}-0.003 \\
(0.008)\end{array}$ & $\begin{array}{l}-0.009 \\
(0.007)\end{array}$ \\
\hline External distance & $\begin{array}{c}0.000 \\
(0.010)\end{array}$ & $\begin{array}{l}-0.008 \\
(0.011)\end{array}$ & $\begin{array}{c}0.014 \\
(0.024)\end{array}$ & $\begin{array}{c}0.008 \\
(0.015)\end{array}$ & $\begin{array}{c}0.020 \\
(0.012)\end{array}$ \\
\hline Internal distance & $\begin{array}{l}-0.051^{\star *} \\
(0.016)\end{array}$ & $\begin{array}{l}-0.081^{\star *} \\
(0.014)\end{array}$ & $\begin{array}{c}0.002 \\
(0.023)\end{array}$ & $\begin{array}{c}-0.089 * * \\
(0.012)\end{array}$ & $\begin{array}{c}-0.118^{\star *} \\
(0.010)\end{array}$ \\
\hline Observations & 1757 & 2015 & 2399 & 2382 & 2310 \\
\hline R-squared & 0.52 & 0.59 & 0.50 & 0.72 & 0.78 \\
\hline
\end{tabular}

Robust standard errors in parentheses * significant at 5\%; ** significant at 1\%

A constant term is included in the regression (but not reported). Instruments used for GDP per capita (province) and the manufacturing wage are the percentages of the population with primary, junior, senior and university education. 
Table 3: Extensive Margin, Processing Exports (Unweighted)

\begin{tabular}{lccccc}
\multicolumn{7}{c}{ Domestic Firms } \\
\hline \hline GDP per capita & $\mathbf{1 9 8 8}$ & $\mathbf{1 9 9 1}$ & $\mathbf{1 9 9 4}$ & $\mathbf{1 9 9 7}$ & $\mathbf{2 0 0 0}$ \\
$\quad$ (province) & $0.422^{\star \star}$ & $0.327^{\star \star}$ & $0.355^{\star \star}$ & $0.862^{\star \star}$ & $0.782^{\star \star}$ \\
Manufact wage & $(0.066)$ & $(0.057)$ & $(0.033)$ & $(0.051)$ & $(0.048)$ \\
& 0.512 & $1.012^{\star \star}$ & $0.576^{\star \star}$ & $-0.374^{\star \star}$ & 0.014 \\
GDP per capita & $(0.281)$ & $(0.194)$ & $(0.068)$ & $(0.078)$ & $(0.110)$ \\
$\quad($ country) & -0.000 & -0.000 & 0.002 & 0.000 & -0.002 \\
Population & $(0.002)$ & $(0.002)$ & $(0.002)$ & $(0.002)$ & $(0.003)$ \\
(province) & $0.362^{\star \star}$ & $0.348^{\star \star}$ & $0.269^{\star \star}$ & $0.356^{\star \star}$ & $0.432^{\star \star}$ \\
Population & $(0.059)$ & $(0.040)$ & $(0.011)$ & $(0.010)$ & $(0.014)$ \\
(country) & -0.002 & 0.002 & -0.000 & -0.006 & $-0.013^{\star}$ \\
External distance & $(0.005)$ & $(0.005)$ & $(0.004)$ & $(0.004)$ & $(0.006)$ \\
& 0.012 & -0.007 & 0.015 & 0.006 & $0.027^{\star}$ \\
Internal distance & $(0.013)$ & $(0.011)$ & $(0.009)$ & $(0.010)$ & $(0.013)$ \\
& $-0.035^{\star \star}$ & -0.004 & $-0.055^{\star \star}$ & $-0.088^{\star \star}$ & $-0.142^{\star \star}$ \\
\hline Observations & $(0.008)$ & $(0.007)$ & $(0.007)$ & $(0.005)$ & $(0.008)$ \\
R-squared & 1272 & 1514 & 1704 & 1664 & 1753 \\
\hline
\end{tabular}

Foreign-Owned Firms

\begin{tabular}{|c|c|c|c|c|c|}
\hline & 1988 & 1991 & 1994 & 1997 & 2000 \\
\hline \multirow{2}{*}{$\begin{array}{l}\text { GDP per capita } \\
\text { (province) }\end{array}$} & -0.299 & 0.185 & $0.934^{\star \star}$ & $0.883^{\star \star}$ & $0.919 * \star$ \\
\hline & $(0.153)$ & $(0.099)$ & $(0.070)$ & $(0.109)$ & $(0.116)$ \\
\hline \multirow[t]{2}{*}{ Manufact wage } & $3.562^{\star \star}$ & $2.474^{\star \star}$ & $0.359^{*}$ & $0.463^{*}$ & $0.680^{\star *}$ \\
\hline & $(0.700)$ & $(0.499)$ & $(0.159)$ & $(0.184)$ & $(0.229)$ \\
\hline \multirow{2}{*}{$\begin{array}{l}\text { GDP per capita } \\
\text { (country) }\end{array}$} & $-0.017^{\star *}$ & -0.003 & 0.004 & 0.002 & -0.003 \\
\hline & $(0.005)$ & $(0.005)$ & $(0.004)$ & $(0.004)$ & $(0.004)$ \\
\hline \multirow{2}{*}{$\begin{array}{l}\text { Population } \\
\text { (province) }\end{array}$} & 0.220 ** & $0.413^{\star \star}$ & $0.505^{\star \star}$ & $0.562^{\star \star}$ & $0.652^{\star *}$ \\
\hline & $(0.064)$ & $(0.038)$ & $(0.030)$ & $(0.034)$ & $(0.028)$ \\
\hline \multirow{2}{*}{$\begin{array}{l}\text { Population } \\
\text { (country) }\end{array}$} & $-0.027^{*}$ & -0.006 & -0.001 & -0.001 & 0.008 \\
\hline & $(0.013)$ & $(0.011)$ & $(0.007)$ & $(0.009)$ & $(0.009)$ \\
\hline \multirow[t]{2}{*}{ External distance } & $0.205^{\star \star}$ & $0.050^{*}$ & 0.028 & 0.020 & $0.039 *$ \\
\hline & $(0.038)$ & $(0.023)$ & $(0.018)$ & $(0.018)$ & $(0.020)$ \\
\hline \multirow[t]{2}{*}{ Internal distance } & $-0.190 * \star$ & $-0.150 * \star$ & $-0.124^{\star \star}$ & $-0.182^{\star *}$ & $-0.170^{\star \star}$ \\
\hline & $(0.022)$ & $(0.015)$ & $(0.013)$ & $(0.011)$ & $(0.011)$ \\
\hline Observations & 1104 & 1269 & 1462 & 1493 & 1518 \\
\hline R-squared & 0.26 & 0.30 & 0.65 & 0.65 & 0.72 \\
\hline
\end{tabular}

Robust standard errors in parentheses * significant at 5\%; ** significant at 1\%

A constant term is included in the regression (but not reported). Instruments used for GDP per capita (province) and the manufacturing wage are the percentages of the population with primary, junior, senior and university education. 
Table 4: Extensive Margin, Processing Exports (Weighted)

\begin{tabular}{lccccc}
\hline & $\mathbf{1 9 8 8}$ & $\mathbf{1 9 9 1}$ & $\mathbf{1 9 9 4}$ & $\mathbf{1 9 9 7}$ & $\mathbf{2 0 0 0}$ \\
\hline \hline GDP per capita & $1.111^{\star \star}$ & $0.237^{\star \star}$ & $0.273^{\star \star}$ & $0.736^{\star \star}$ & $0.759^{\star \star}$ \\
(province) & $(0.339)$ & $(0.050)$ & $(0.088)$ & $(0.095)$ & $(0.101)$ \\
Manufact wage & $-0.931^{\star}$ & $0.236^{\star}$ & $0.877^{\star \star}$ & -0.086 & 0.166 \\
& $(0.396)$ & $(0.095)$ & $(0.180)$ & $(0.112)$ & $(0.155)$ \\
GDP per capita & 0.002 & -0.001 & -0.003 & -0.001 & -0.002 \\
$\quad$ (country) & $(0.004)$ & $(0.002)$ & $(0.004)$ & $(0.003)$ & $(0.005)$ \\
Population & $0.771^{\star \star}$ & $0.163^{\star \star}$ & $0.223^{\star \star}$ & $0.348^{\star \star}$ & $0.461^{\star \star}$ \\
(province) & $(0.237)$ & $(0.027)$ & $(0.033)$ & $(0.024)$ & $(0.024)$ \\
Population & -0.005 & -0.002 & 0.003 & -0.001 & -0.009 \\
(country) & $(0.018)$ & $(0.004)$ & $(0.007)$ & $(0.006)$ & $(0.008)$ \\
External distance & 0.004 & 0.007 & 0.023 & 0.003 & 0.008 \\
& $(0.019)$ & $(0.009)$ & $(0.014)$ & $(0.011)$ & $(0.015)$ \\
Internal distance & -0.012 & $-0.022^{\star \star}$ & -0.003 & $-0.068^{\star \star}$ & $-0.126^{\star \star}$ \\
& $(0.034)$ & $(0.008)$ & $(0.017)$ & $(0.009)$ & $(0.013)$ \\
\hline Observations & 1272 & 1514 & 1704 & 1664 & 1753 \\
R-squared & 0.54 & 0.40 & 0.52 & 0.78 & 0.81 \\
\hline
\end{tabular}

Foreign-Owned Firms

\begin{tabular}{lccccc}
\hline & $\mathbf{1 9 8 8}$ & $\mathbf{1 9 9 1}$ & $\mathbf{1 9 9 4}$ & $\mathbf{1 9 9 7}$ & $\mathbf{2 0 0 0}$ \\
\hline \hline GDP per capita & -0.746 & $0.347^{\star}$ & $0.709^{\star \star}$ & $0.756^{\star \star}$ & $1.083^{\star \star}$ \\
(province) & $(0.505)$ & $(0.136)$ & $(0.143)$ & $(0.139)$ & $(0.209)$ \\
Manufact wage & $5.028^{\star}$ & $1.370^{\star \star}$ & $0.890^{\star \star}$ & 0.413 & 0.147 \\
& $(2.521)$ & $(0.405)$ & $(0.287)$ & $(0.212)$ & $(0.362)$ \\
GDP per capita & -0.005 & -0.009 & 0.005 & -0.005 & -0.011 \\
$\quad$ (country) & $(0.013)$ & $(0.009)$ & $(0.011)$ & $(0.008)$ & $(0.007)$ \\
Population & 0.141 & $0.341^{\star \star}$ & $0.393^{\star \star}$ & $0.456^{\star \star}$ & $0.553^{\star \star}$ \\
(province) & $(0.201)$ & $(0.058)$ & $(0.049)$ & $(0.036)$ & $(0.032)$ \\
Population & 0.016 & -0.013 & 0.005 & -0.003 & -0.007 \\
(country) & $(0.049)$ & $(0.017)$ & $(0.012)$ & $(0.012)$ & $(0.012)$ \\
External distance & 0.150 & 0.065 & 0.006 & 0.014 & 0.031 \\
& $(0.079)$ & $(0.034)$ & $(0.039)$ & $(0.024)$ & $(0.020)$ \\
Internal distance & $-0.388^{\star \star}$ & $-0.176^{\star \star}$ & $-0.104^{\star \star}$ & $-0.188^{\star \star}$ & $-0.165^{\star \star}$ \\
& $(0.085)$ & $(0.026)$ & $(0.029)$ & $(0.019)$ & $(0.019)$ \\
\hline Observations & 1104 & 1269 & 1462 & 1493 & 1518 \\
R-squared & 0.45 & 0.53 & 0.56 & 0.69 & 0.76 \\
\hline Robust standard error
\end{tabular}

Robust standard errors in parentheses * significant at 5\%; ** significant at $1 \%$

A constant term is included in the regression (but not reported). Instruments used for GDP per capita (province) and the manufacturing wage are the percentages of the population with primary, junior, senior and university education. 
Figure 1(A): Chinese Manufacturing Exports 2002, By Destination, billion \$

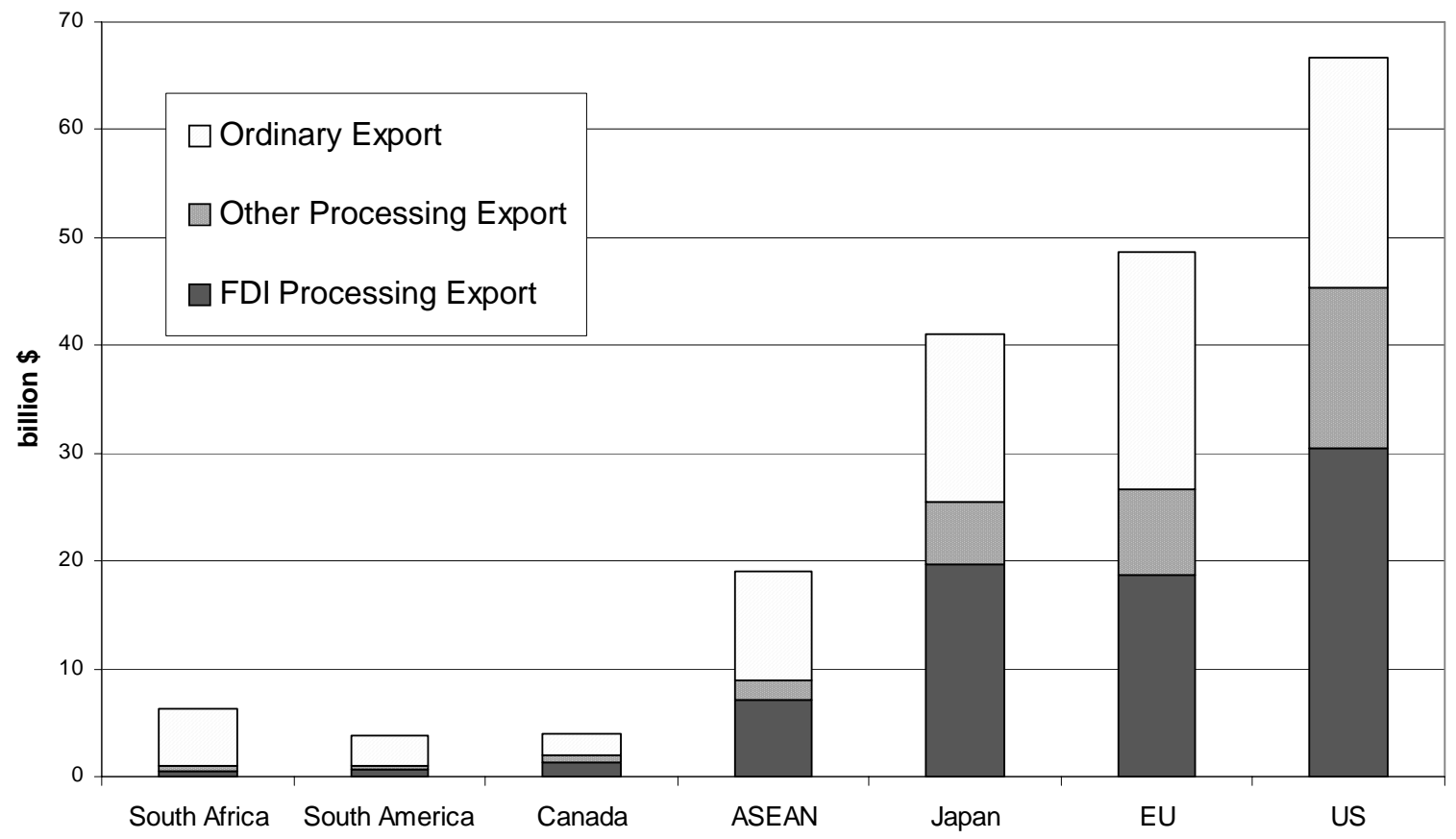

Figure 1(B): China Manufacturing Exports 2002, By Destination, Percent

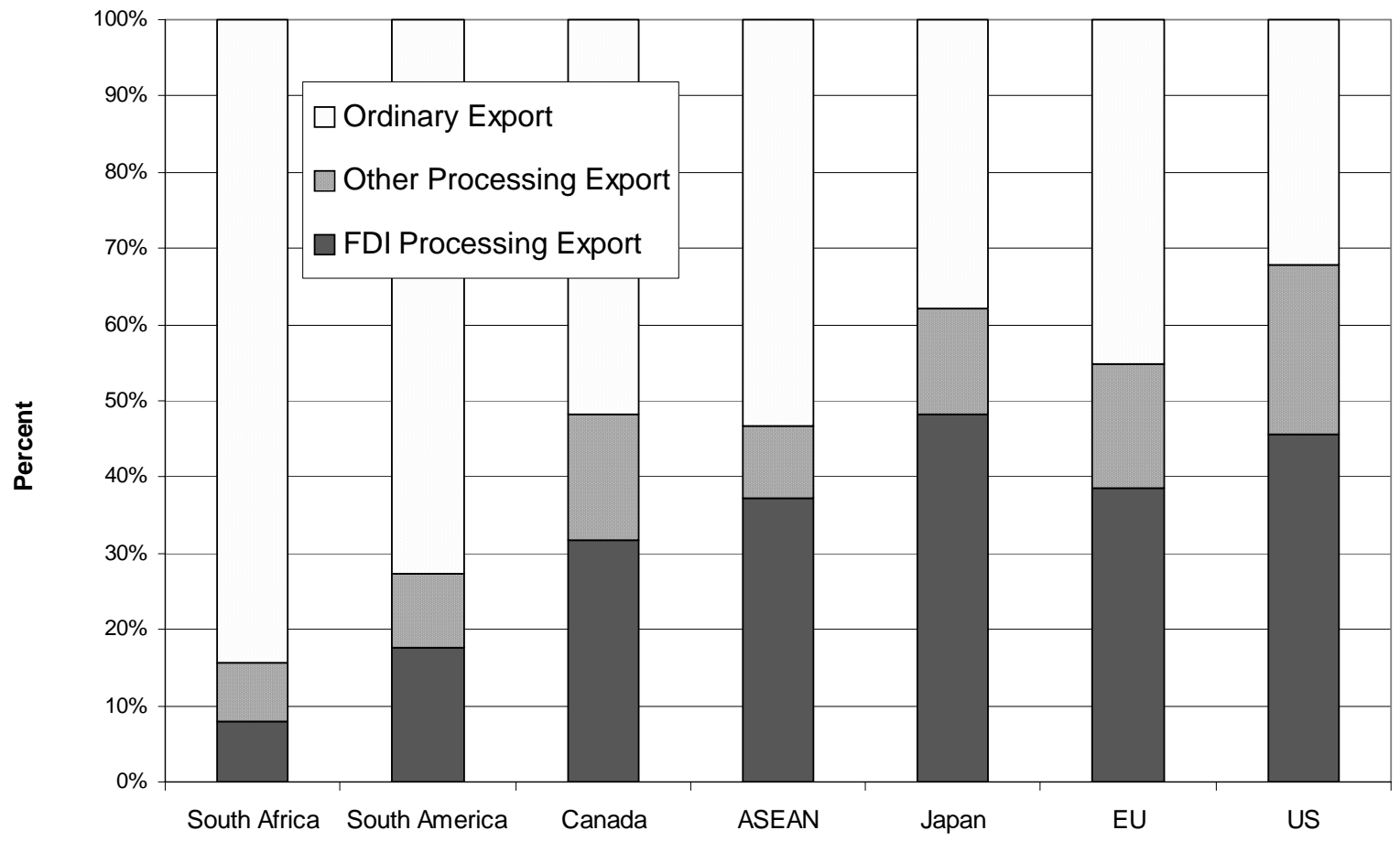


Figure 2(A): China Manufacturing Exports, By Source Region, billion\$

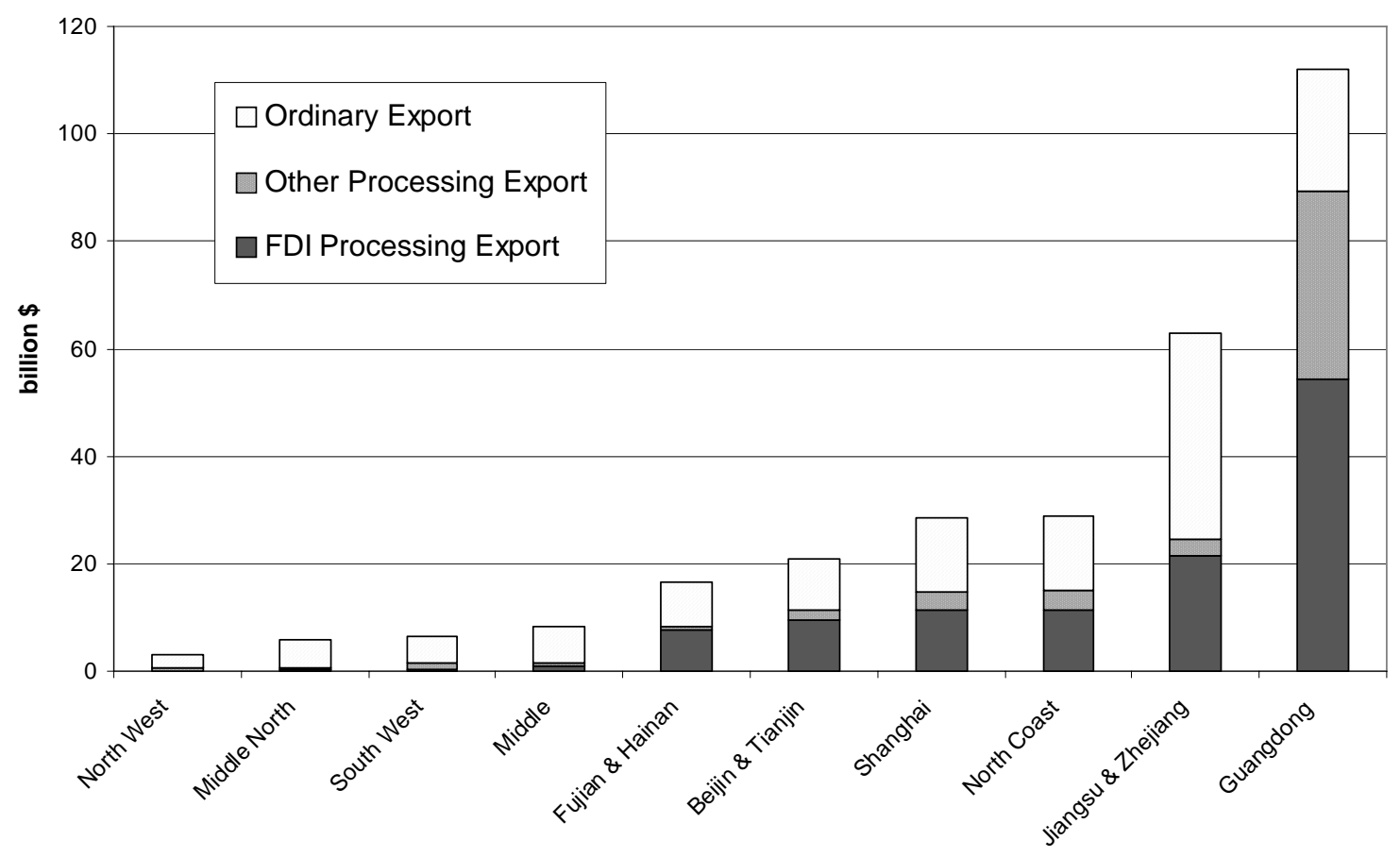

Figure 2(B): China Manufacturing Exports, By Source Region, Percent

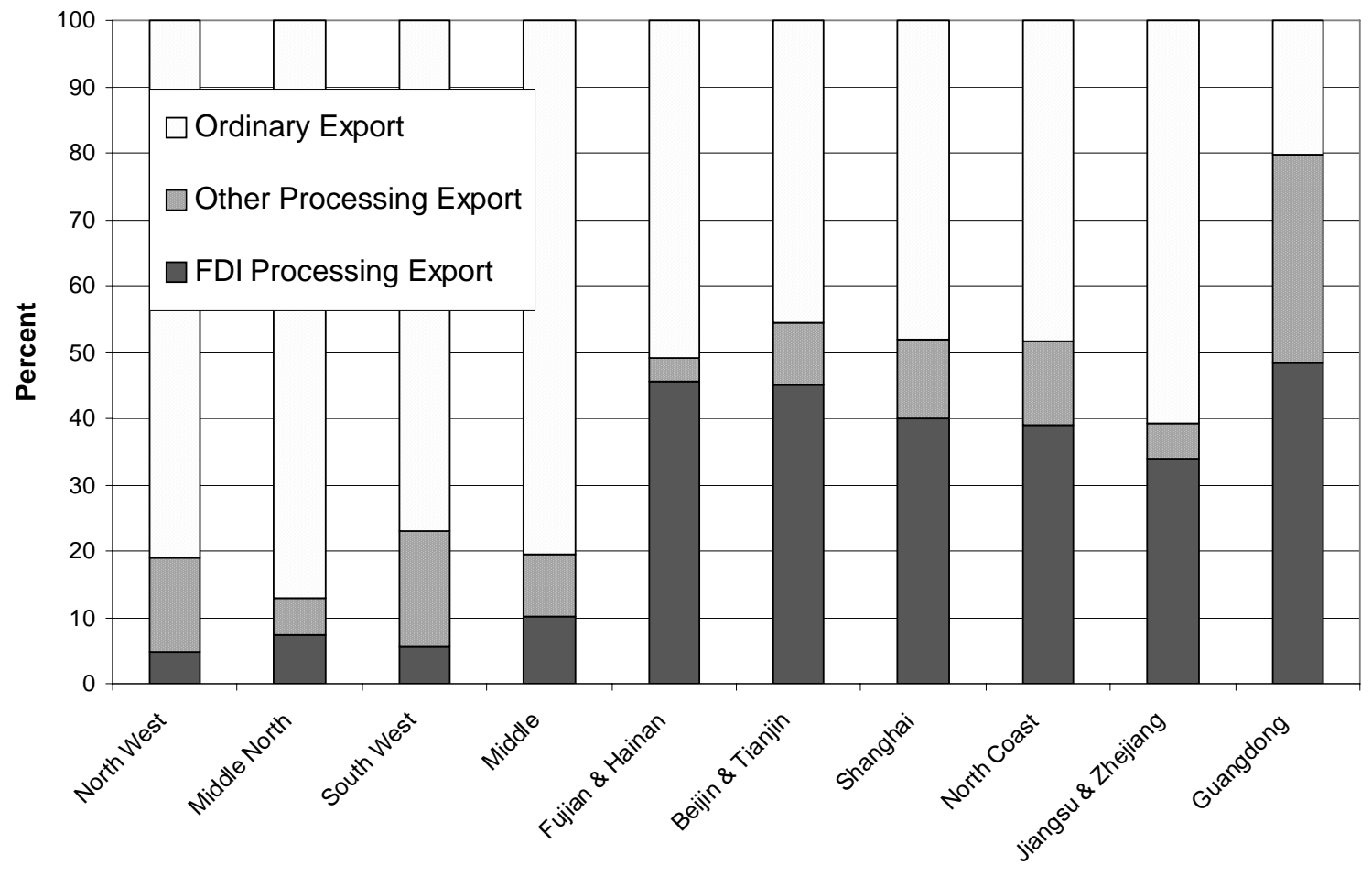




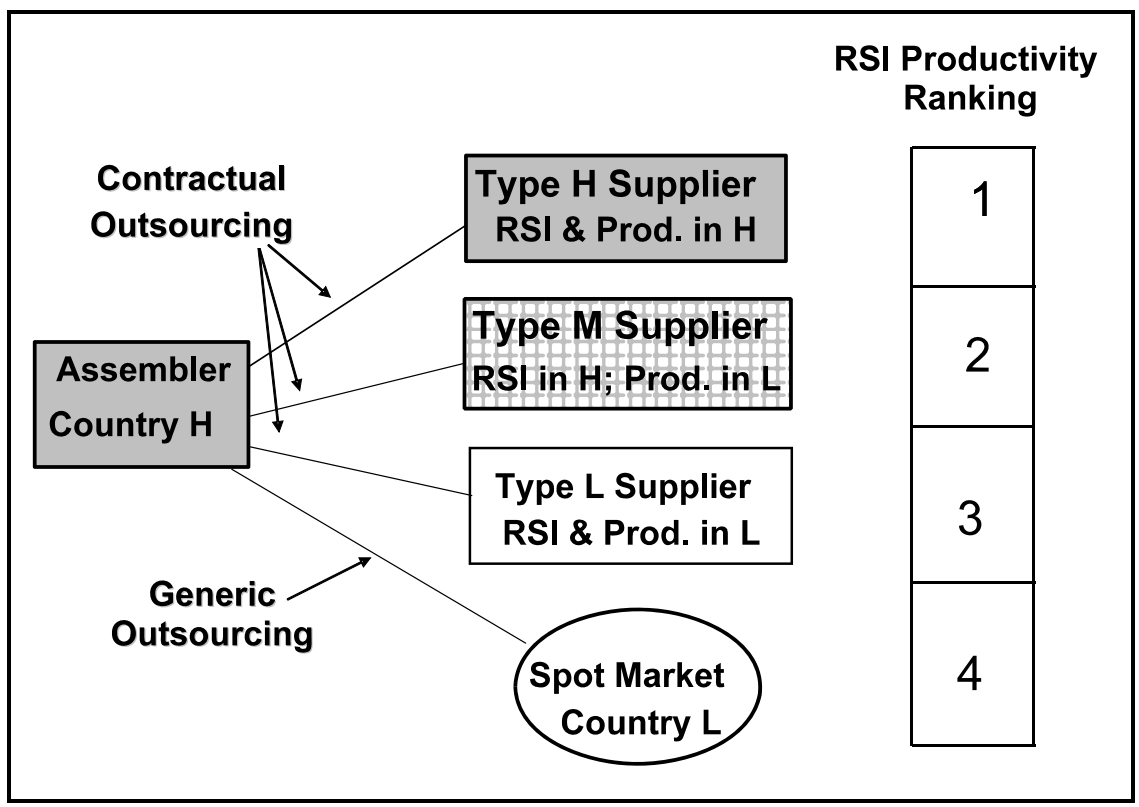

Figure 3: Forms of contractual and generic outsourcing 